Review

\title{
Valorisation of wood fly ash on concrete
}

\author{
E.R. Teixeira ${ }^{\mathrm{a}, *}$, A. Camões ${ }^{\mathrm{a}}$, F.G. Branco ${ }^{\mathrm{b}}$ \\ ${ }^{a}$ CTAC, Department of Civil Engineering, School of Engineering, University of Minho, Campus de Azurém, 4800-058 Guimarães, Portugal \\ ${ }^{\mathrm{b}}$ INESC - Coimbra, Department of Civil Engineering, University of Coimbra, Rua Luís Reis Santos - Pólo II da Universidade, 3030 - 788 Coimbra, Portugal
}

A R T I C L E I N F O

\section{Keywords:}

Wood fly ash

Coal fly ash

Concrete

Cement replacement

Sustainability

\begin{abstract}
A B S T R A C T
Wood fly ash (WFA) is a waste material produced in power plants as result of forest residues combustion to produce power and heat. In countries like Portugal, this waste is disposed of in landfills. Since this material shows pozzolanic characteristics, several studies have been done to evaluate its use as a construction material. This work shows an overview of some published results about the effect of the utilisation of WFA, as a supplementary cementitious material, on the durability and quality of concrete. The results showed that the increase on the wood fly ash content leads to a negative effect on the concrete properties when compared with a conventional concrete. However, the results showed that the behaviour of wood fly ash concrete is very similar to the coal fly ash concrete, which is the most pozzolanic material used in the world. In terms of durability, it was verified that WFA improved the most of the durability characteristics with the exception of carbonation resistance. However, more experimental analysis needs to be developed in terms of wood fly ash concrete durability. Results suggested that using wood fly ash to replace cement is a valuable sustainable option for concrete production. This manuscript discusses the key factors and attempts to provide new information about the application of the wood fly ash on concrete.
\end{abstract}

\section{INTRODUCTION}

Portland cement is one of the most used materials in the construction field (Demis et al., 2014), namely in the concrete industry. Cement production leads to a large consumption of natural resources and high emissions of carbon dioxide $\left(\mathrm{CO}_{2}\right)$ to the atmosphere (Aranda Usón et al., 2013; Benhelal et al., 2013; Fairbairn et al., 2010). Furthermore, it is well known that $\mathrm{CO}_{2}$ is a contributing factor to global warming. Some products or residues generated during the activity of various industrial sectors can react with calcium hydroxide resulting in calcium silicate hydrates such as the ones formed during cement hydration, thus having similar properties to Portland cement and are denominated as pozzolans. Therefore, its utilisation as cement replacement seems to be a promising solution to minimise these problems (Demis et al., 2014).

Pozzolans are natural or artificial materials containing silica in a reactive form. These materials have the capacity, in the presence of moisture, to chemically react with calcium hydroxide at ordinary temperatures to form compounds that have cementitious properties (Neville, 1995). Examples of pozzolanic materials are ground granulated blast furnace slag, fly ash from thermal power plant (CFA) and silica fume. Their functionality has been demonstrated in several studies in terms of technical, environmental and economic benefits
(Ahmaruzzaman, 2010; Nochaiya et al., 2010; Sabet et al., 2013). Recent studies show that the utilisation of pozzolanic materials from biomass can be feasible (Batt and Garg, 2017; Chalee et al., 2013; Wang, 2015).

Biomass is considered a renewable energy source and is used for energy production in the European Union. In Portugal, some sectors such as pulp and paper, furniture and cork are heavy consumers (Tarelho et al., 2015, 2012). Some of those sectors also use forest biomass residues for heat and power production (Tarelho et al., 2012). The forest biomass residues are a result of its ongoing work, during the preparation of feedstock and forest maintenance (Cordeiro et al., 2008; Tarelho et al., 2015, 2012). Combustion is the most used operation to produce heat and power using biomass residues as fuel (Barbosa et al., 2013b). However, during biomass combustion, a high content of ashes is produced, and this is an issue for biomass valorisation (Tarelho et al., 2012).

The quantity and quality of ashes produced during biomass conversion are influenced by the characteristics of biomass, such as: agriculture waste, herbaceous biomass, wood or bark (Rajamma et al., 2009) and by operation conditions (Tarelho et al., 2012). The characteristics of ashes and their management are very important in terms of operating and environmental aspects (Tarelho et al., 2012). In

\footnotetext{
* Corresponding author.

E-mail address: id5470@alunos.uminho.pt (E.R. Teixeira).
} 
Portugal, fly ash from biomass combustion is classified as solid waste and is usually managed by disposal in landfill. However, landfill disposal has economic, environmental and sustainable issues. Therefore, it is important to find other applications for fly ashes from biomass combustion (Miller et al., 2006; Tarelho et al., 2012).

Using wood fly ash (WFA) as partial cement replacement in construction materials minimises the use of natural resources in cement production (Tarelho et al., 2015), the mitigation of greenhouse gas emissions and a better solution for ash management. Some studies showed good performance when blends of coal and WFA or only biomass ash were used in concrete (Ban and Ramli, 2011; Barbosa et al., 2013b; Rajamma et al., 2009). However, some technical issues, such as commercial barriers and concerns about the availability and quantity of biomass ash are still issues when those ashes are used at industrial levels (Barbosa et al., 2013b).

In this work, a study about the utilisation of WFA with wood origin as a partial cement replacement and its effect on several aspects related to concrete such as workability, durability, quality and sustainability was carried out. The main aim of this study is to understand the possibility of using this material to produce concrete.

\section{Wood fly ash characteristics}

The physical and chemical characterisation of fly ashes is important to understand the benefits of using it (Siddique, 2012). The WFA is divided into different flows, and this division is made in the places where they are sampled such as: super-heaters, economizers, and control devices (cyclones, bag filters and electrostatic precipitator) (Tarelho et al., 2012). The different flows are usually mixed and managed together but each one has distinct properties (Capablo et al., 2009; Liao et al., 2007; Loo and Van Koppejan, 2012; Obernberger, 2009; Tarelho et al., 2015, 2012; Teixeira et al., 2013).

The WFA is influenced by the technology used for biomass combustion, such as: grates, fluidised beds and fixed beds (Girón et al., 2013; Liao et al., 2007), but also by the type of fuel (biomass) (Girón et al., 2013; Teixeira et al., 2012; Vassilev et al., 2013a,b, 2010) and operation conditions (Miller et al., 2006; Steenari and Karlfeldt Fedje, 2010; Tarelho et al., 2012).

This study focuses on WFA with wood origin, because this is the most produced type in Portuguese industries. In Portugal, this ashes are a result of thermochemical conversion of a mixture of residual forest biomass (essentially biomass derived from eucalyptus and pine, but also in small amounts from acacia) resulting from forest management practices as logging activities related to the harvesting of wood for the pulp and paper industries and other industrial wood sectors, and also from forest maintenance for wildfire prevention (Tarelho et al., 2015).

The WFA were studied in terms of physical and chemical characteristics, by several methods such as XRD, XRF, SEM/EDS. The following sections give the discussion of wood fly ash in terms of physical, mineralogical and chemical characteristics. During the study a comparison with coal fly ash is also made, because this type of ash is the most used pozzolanic material in concrete production.

\subsection{Physical and mineralogical characteristics}

Wood fly ash presented an irregular morphology in terms of size and shape of particles, showing a wide range of particle shape and size (Fig. 1). Some particles are angular, and have rough textures, some particles are spherical with some impurities attached to their surface and some with smooth surfaces (Lessard et al., 2017; Tarelho et al., 2011).

In terms of density, Berra et al. (2015) studied three type of wood fly ash and observed that the values for the density varied between 2.35 and $2.76 \mathrm{~g} / \mathrm{cm}^{3}$. Rajamma et al. $(2015,2009)$ observed that for two wood fly ashes collected in two Portuguese facilities (one collected in a biomass thermal power plant and the second one collected from a biomass co-generation plant) the specific surface area and bulk density were respectively $40 \mathrm{~m}^{2} / \mathrm{g}, 2.59 \mathrm{~g} / \mathrm{cm}^{3}$ for one of them and $8 \mathrm{~m}^{2} / \mathrm{g}$, $2.54 \mathrm{~g} / \mathrm{cm}^{3}$ for the other. Tarelho et al. (2011) studied two wood fly ashes (one from wood combustion on a fluidised bed reactor and the other from wood combustion in a grate combustor) and observed specific surface areas of 13 and $14 \mathrm{~m}^{2} / \mathrm{g}$ (determined by the BET method) and a bulk density of $2.23 \mathrm{~g} / \mathrm{cm}^{3}$. These results showing that in general the bulk density of wood fly ashes varied between 2200 to $2800 \mathrm{~kg} / \mathrm{m}^{3}$ and the surface area has a higher dispersion that is related with the combustor equipment $\left(8-40 \mathrm{~m}^{2} / \mathrm{g}\right)$.

The physical characteristics of size fractionated wood fly ash were studied by Barbosa et al. (2013a). It was observed that these ashes consisted of finer particles and in most of them the mass was separated in three size ranges: $48 \%$ in the $20-50 \mu \mathrm{m}$ range, $36.3 \%$ in the range of $50-200 \mu \mathrm{m}$ and $10.5 \%$ in the range of $200-500 \mu \mathrm{m}$. However, the particle size of wood fly ash can be significantly different (Barbosa et al., 2013a; Sarabèr and Haasnoot, 2012), because it depends on the combustion technology and the biomass origin.

Wang et al. (2008c) and Lessard et al. (2017) studied the particle size distribution of five different types of ashes and the results are shown in Figs. 2 and 3. They observed that Class C and Class F CFA according to (ASTM C618-15, 2015) have similar particle size distribution and most of particles are between 3 to $50 \mu \mathrm{m}$ (Wang et al., 2008c). However, WFA has particles with a much larger size than the other fly ashes. Larger sized particles, when compared to cement particle size distribution, are also observed by Lessard et al. (2017).

\subsection{Chemical compositions}

Table 1 shows that the loss of ignition (LOI) content of wood fly ash is significantly higher than coal fly ash. As it can be seen a wide range can be observed for the LOI values for the wood fly ashes (0.5-25.0\% wt). The LOI content is a very important parameter since it is known that fly ash with high LOI values may affect the concrete properties. Fly ashes with high LOI absorbed more water and chemical admixtures, for example the superplasticizer resulting in increasing the slump loss, decreasing the air-entraining effect and bleeding and decreasing the strength of concrete (Berry and Malhotra, 1980; Huang et al., 2013; Lane and Best, 1982).

Lime and quartz are the oxides at higher concentration in the chemical composition of ashes (Table 1) (4.8-52.1\%wt of $\mathrm{SiO}_{2}$ and 8.5-53.4\%wt of $\mathrm{CaO}$, being once again observed a wide dispersion in the content of each elements), but several other oxides are present in a significant concentration such as aluminium, potassium, iron, sodium, magnesium, chloride and sulphur (Chowdhury et al., 2015; Dahl et al., 2010, 2009; Esteves et al., 2012; Girón et al., 2013; Liao et al., 2007; Maschio et al., 2011; Pitman, 2006; Rajamma et al., 2009; Sarabèr and Haasnoot, 2012; Tarelho et al., 2012, 2011; Teixeira et al., 2019; Vamvuka and Kakaras, 2011; Velay-Lizancos et al., 2017).

The high content of lime is related with the presence of this oxide in the chemical composition of biomass (Vassilev et al., 2010) that is released during its combustion. The high content of silicium compounds is also related to the chemical composition of biomass (mostly with the inorganic part-ash), but also related with the inert material, e.g. soil particles, which are fed mixed with biomass during combustion (Vassilev et al., 2010). The high silica content is explained by the fine particles from the inert material fed with biomass and in the case of the bubbling fluidised bed reactor, by the fine particles that belong to the bed sand, which are carried out with the combustion flue gas and captured by the control devices (Tarelho et al., 2015, 2012; Teixeira et al., 2013; Vassilev et al., 2013a, 2010).

WFA has a high content of heavy metals, e.g. Cr, Cd, Pb, Zn, Co, As, and some of them present organic compounds in their composition, e.g. $\mathrm{PAH}$, and this has an environmental importance (Barbosa et al., 2013a; Dahl et al., 2010; Demirbas, 2005; Khan et al., 2009; Loo and Van Koppejan, 2012; Obernberger, 2009; Pettersson et al., 2008; Tarelho 

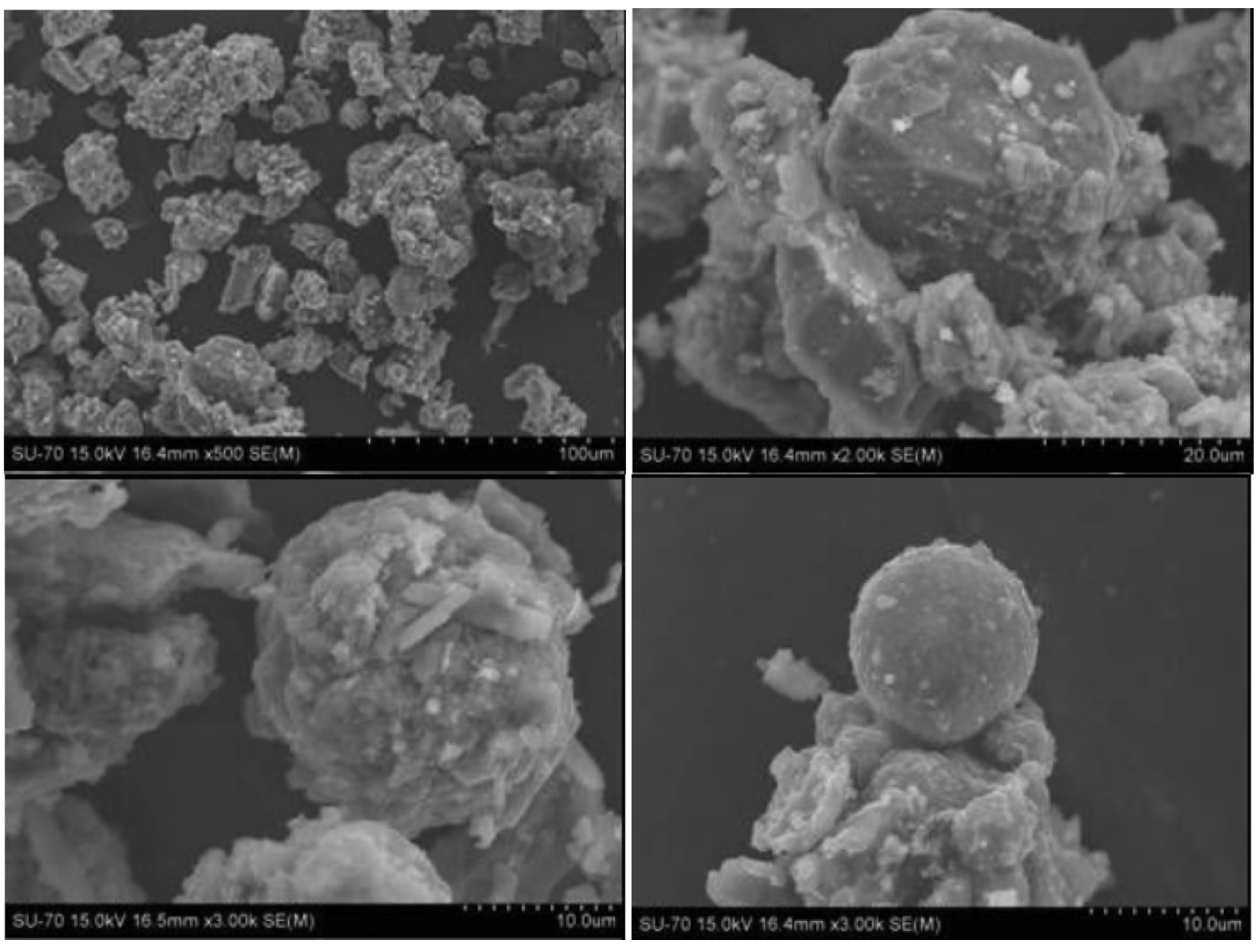

Fig. 1. Microscopic aspect (SEM images) of the wood fly ash from fluidized bed (Tarelho et al., 2011).

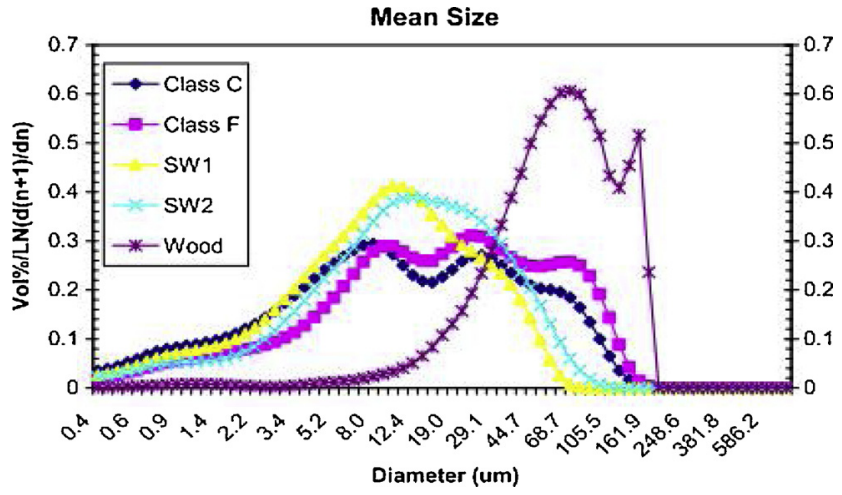

Fig. 2. Particle size distribution of fly ashes with different origins: coal (Class $\mathrm{C}$ and Class F), sawdust (SW1 and SW2) and wood (Wang et al., 2008c).

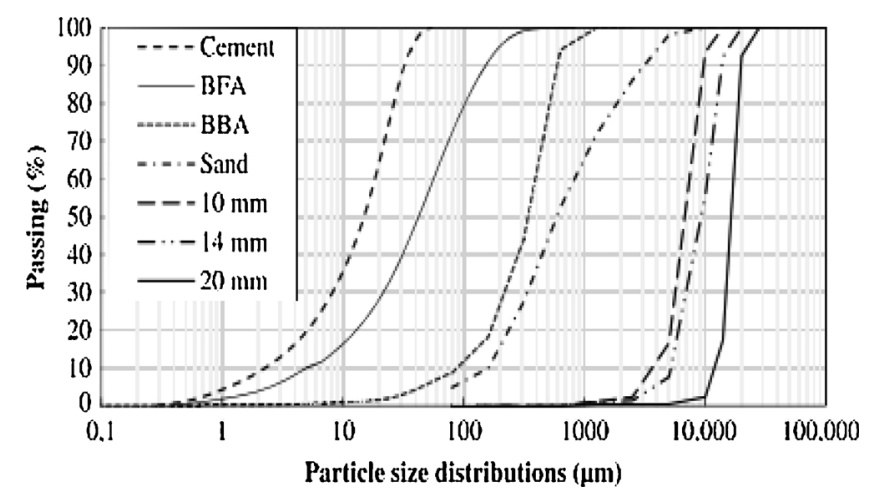

Fig. 3. Particle size distribution of wood fly ash (WFA), biomass bottom fly ash (BBA), cement, sand and aggregates (10, 14 and $20 \mathrm{~mm}$ ) (Lessard et al., 2017).

\section{et al., 2015, 2012).}

As a general trend, WFA are different from coal fly ashes, they have higher content of $\mathrm{Ag}, \mathrm{B}, \mathrm{Br}, \mathrm{Ca}, \mathrm{Cl}, \mathrm{Cu}, \mathrm{Ga}, \mathrm{Hg}, \mathrm{I}, \mathrm{Mg}, \mathrm{Mn}, \mathrm{Mo}, \mathrm{Na} \mathrm{P}, \mathrm{Rb}$,
$\mathrm{Sr}, \mathrm{Te}, \mathrm{Zn}$ and $\mathrm{K}$, less $\mathrm{Al}$ and more variety on composition and on inorganic content material. They present higher content/values of dry water-soluble residue, $\mathrm{pH}$, carbonates, chlorides, oxyhydroxides, phosphates and water-soluble components. Otherwise, presents lower contents/values of Al, As, Au, Ba, Be, Bi, Cd, Ce, Co, Cs, Dy, Er, Eu, F, $\mathrm{Fe}, \mathrm{Gd}, \mathrm{Ge}, \mathrm{Li}, \mathrm{Ni}$, a lower ash-fusion temperatures, lower bulk density, less content of silicates and sulphates-sulphides (Ahmaruzzaman, 2010; Dahl et al., 2012; Demirbas, 2005; Vassilev et al., 2013a,b, 2010, 2014a,b; Wang et al., 2008c).

\subsection{Morphology}

The elemental chemical analysis and high $\mathrm{pH}$ are an indication that some of the metals presented in WFA may be in the form of basic metal salts, oxides or hydroxides (Vassilev et al., 2013a). To better understand the metal forms presented in ashes, some authors (Berra et al., 2015; Dahl et al., 2012, 2010, 2009; Davidsson et al., 2007; Esteves et al., 2012; Girón et al., 2013; Maschio et al., 2011; Rajamma et al., 2009; Sarabèr and Haasnoot, 2012; Singh et al., 2011; Steenari and Karlfeldt Fedje, 2010; Tkaczewska and Małolepszy, 2009; Wang et al., 2008a) carried out X-Ray Diffraction (XRD) analysis on different types of WFA. The results achieved reported the presence of calcium compounds $\left(\mathrm{CaO}, \mathrm{Ca}_{2} \mathrm{Fe}_{2} \mathrm{O}_{5}, \mathrm{CaCO}_{3}, \mathrm{CaSO}_{4}, \mathrm{CaAl}_{2} \mathrm{SiO}_{7}, \mathrm{CaMgSi}_{2} \mathrm{O}_{6}, \mathrm{CaMg}\left(\mathrm{CO}_{3}\right)_{2}\right)$, but also compounds with silica, sodium, magnesium, iron, potassium and aluminium $\left(\mathrm{SiO}_{2}, \mathrm{MgO}, \mathrm{Fe}_{2} \mathrm{O}_{3}, \mathrm{Al}_{2} \mathrm{O}_{3}, \mathrm{KAlSi}_{3} \mathrm{O}_{8}, \mathrm{~K}_{2} \mathrm{SO}_{4}, \mathrm{KCl}\right.$, $\mathrm{NaAlSi}_{3} \mathrm{O}_{8}, \mathrm{NaAl}_{3} \mathrm{O}_{8}$ ), which confirms the chemical results.

Several ash materials have cementitious properties as they react with moderate amounts of water (Tosti et al., 2018). Usually, the main mineral present in WFA are those described before. However when these ashes react with water, secondary hydrated minerals, such as ettringite, portlandite and calcite, are formed during the process, but also can form calcium-silicate-hydrates, aluminate-hydrates and gypsum (Chaunsali et al., 2018; Eliche-Quesada et al., 2017; Fuller et al., 2018).

During $\mathrm{CaO}$ hydration, portlandite is formed that subsequently reacts with $\mathrm{CO}_{2}$ present in the air and water to form calcium carbonate (Maresca et al., 2019). The carbonation of portlandite is the most 


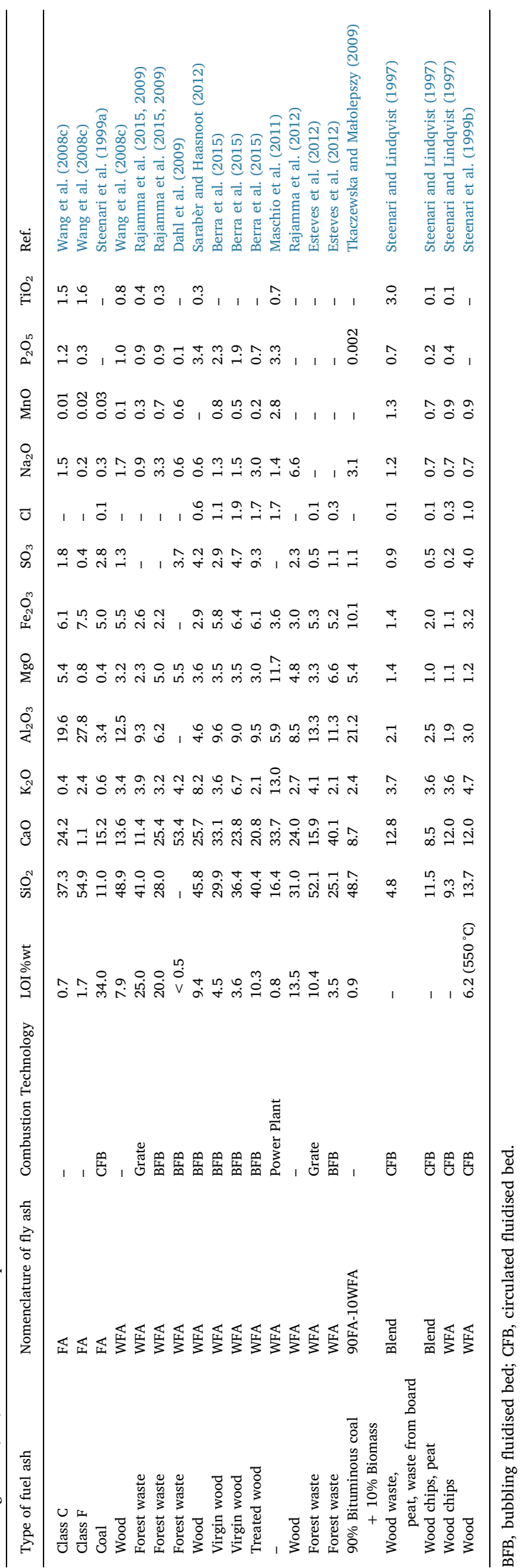


important parameter in the self-hardening properties of WFA, since some XRD analyses of hardened fly ashes showed a lack of lime and portlandite in WFA, lesser than when observed in fresh ashes (Maresca et al., 2017).

The differences among ashes with the same origin can be related to the combustion system, the characteristics of the fluidising agent and the system treatment of the gaseous effluents (Barbosa et al., 2013a). The physical and chemical characteristics of wood fly ash are important parameters to consider in terms of the valorisation of this material, such as its application in construction materials.

In next sections the main goal of this study will be discussed: the influence of wood fly ash on the fresh and hardened properties of concrete. However, some studies that are related with the use of WFA on cement pastes and mortars will also be presented. These studies were chosen taking into account some published literature (Camões et al., 2005; Rubio-Hernández et al., 2012) that shows that the results obtained for the properties of conventional concrete can be predicted with sufficient accuracy using the results obtained in the corresponding mortars.

\section{Legal framework of wood fly ash application on concrete}

WFA has been incorporated into concrete as a substitute for cement (Barbosa et al., 2013b; Horsakulthai et al., 2011; Omran et al., 2018; Sata et al., 2007; Siddique, 2012; Wang et al., 2008b,c) mainly due to its physical and chemical properties. Using of WFA as a partial cement replacement showed many positive effects on cement mixtures, and some of these results are summarised in (Ban and Ramli, 2011; Siddique, 2012). However, there are some WFA that do not have pozzolanic properties.

Some types of WFA are incorporated in construction materials, however there are not adequate standards for using them. Due to this the standards applied to CFA utilisation in concrete were used as a basis for WFA incorporation in concrete (ASTM C618-15, 2015; EN 450-1, 2012).

The ASTM C 618 (ASTM C618-15, 2015) showed two classes for CFA: Class C and Class F. This classification in based on some chemical and physical requirements. One of the biggest differences between Class $\mathrm{C}$ and Class $\mathrm{F}$ is the content of calcium oxide, CFA with $\mathrm{CaO}$ less than $7 \%$ belong to Class F and with more than $20 \%$ belongs to Class C. Most parameters are the same for the two classes: the difference is in the sum of $\mathrm{SiO}_{2}$ plus $\mathrm{Al}_{2} \mathrm{O}_{3}$ plus $\mathrm{Fe}_{2} \mathrm{O}_{3}$ (minimum $70 \%$ for Class $\mathrm{F}$ and minimum $50 \%$ for Class $\mathrm{C}$ ).

The European standard EN 450-1 (EN 450-1, 2012) defines the chemical and physical properties and conformity criteria for using CFA in concrete mixtures. The standard divided the ashes into three categories in terms of LOI (A - $\leq 5 \% \mathrm{wt}, \mathrm{B}-\leq 7 \% \mathrm{wt}$ and C $-9 \% \mathrm{wt}$ ). As can be seen in Table 1 most of the selected biomass ash belongs to category A, one belongs to category B and another one to category C. However, there are some types of WFA that have LOI values higher than $9 \%$, which refers to the last category. In terms of chlorides the content must not exceed $0.1 \% \mathrm{w}$, but most WFA presents higher values (Table 1 ). On the other hand, in terms of $\mathrm{SO}_{3}(\leq 3 \% \mathrm{w}), \mathrm{MgO}(\leq 4 \% \mathrm{w})$ and $\mathrm{P}_{3} \mathrm{O}_{5}$ $(\leq 5 \% \mathrm{w})$ the majority of WFA meets the requirement.

Fig. 4 compares the calcium content with the sum of oxides $\left(\mathrm{SiO}_{2}+\right.$ $\mathrm{Al}_{2} \mathrm{O}_{3}+\mathrm{Fe}_{2} \mathrm{O}_{3}$ ) for wood fly ash and compares it with coal fly ash. Most of the WFA and CFA blends are considered by the (ASTM C618-15, 2015) as Class $\mathrm{C}$ ashes. One important parameter is the sum of $\mathrm{SiO}_{2}$ plus $\mathrm{Al}_{2} \mathrm{O}_{3}$ plus $\mathrm{Fe}_{2} \mathrm{O}_{3}$ in which the standard requirement is minimum $70 \%$, and it can be seen in Fig. 4 that most WFA does not meet the requirement.

It can be seen that the classification of wood fly ash by the European and American standards is very complex. Some WFA is considered as Class C, but the diversity of wood fly ashes in terms of oxides or calcium content does not allow their classification by the standards used for classification of ashes to produce concrete. The classification of WFA

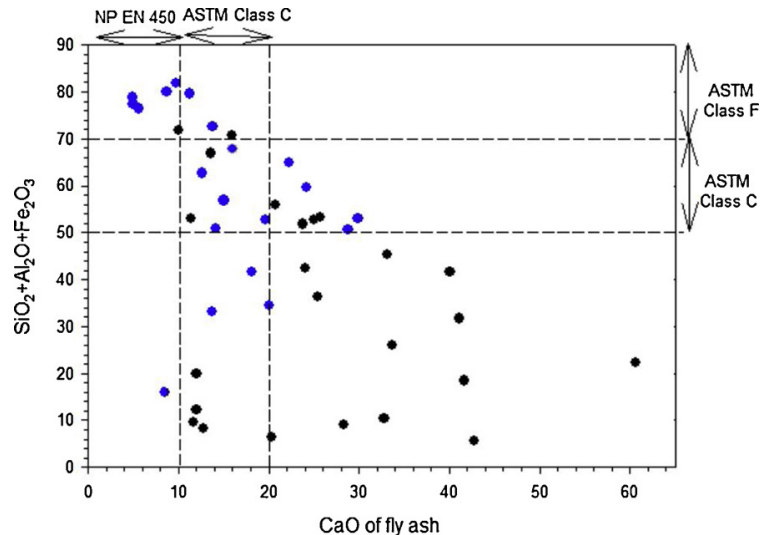

Fig. 4. Relationship between calcium oxide content and the sum of oxides for several WFA (in black) and a comparison with coal fly ashes (in blue) based on (Berra et al., 2015; Chowdhury et al., 2014; Esteves et al., 2012; Illikainen et al., 2014; Koukouzas et al., 2007; Mahmoudkhani et al., 2007; Maschio et al., 2011; Rajamma et al., 2012, 2009, 2015; Ruiz et al., 2017; Sarabèr and Haasnoot, 2012; Shearer et al., 2011; Steenari and Lindqvist, 1997; Steenari et al., 1999a,b; Tkaczewska et al., 2012; Tkaczewska and Małolepszy, 2009; Vamvuka et al., 2008; Wang et al., 2008c). (For interpretation of the references to color in this figure legend, the reader is referred to the web version of this article.)

leads to important issues as wood fly ashes showed a wider variation in the composition than coal fly ash, but generally the wood leads to the production of Class C fly ash (Wang et al., 2008c).

\section{Influence of wood fly ashes on the microstructure of concrete binder}

The microstructure influences the mechanical behaviour of the concretes. Rajamma et al. (2009) studied the composition of pastes made from cement and ashes after 28 days of curing by XRD and thermal analysis (TG/DTA). The main peaks that they observed were calcium hydroxide, calcium aluminium hydrate and calcium silicate, but they also found ettringite, calcite and silica. This result indicated that WFA influenced the phase formation in the mixture. The XRD results were corroborated by the thermal analysis, which showed three peaks related to the decomposition of calcium silicate hydrated and ettringite $\left(135-185^{\circ} \mathrm{C}\right)$, and calcium hydroxide decomposition $\left(525-575^{\circ} \mathrm{C}\right)$. Pastes with ashes presented a decrease in the intensity of the calcium-hydrate $(\mathrm{CH})$ peak. This was due to the fact that the $\mathrm{CH}$ produced is a function of the relative content of alite and belite contained in cement (Rajamma et al., 2009). The variation in $\mathrm{CH}$ indicates the amount of calcium silicate gel formed. The pozzolanic reaction is also responsible for the decrease in the $\mathrm{CH}$. Firstly, the pozzolanic reaction occurs between amorphous siliceous materials and portlandite and forms calcium silicate hydrate (Rajamma et al., 2009). The ratio between calcium/silicate and the water molecules is according to the stoichiometry of the elements presents in the reaction (Rajamma et al., 2009). The third peak was related to the thermal decomposition of calcium carbonate $\left(800^{\circ} \mathrm{C}\right)$.

Maschio et al. (2011) observed in a semi-quantitative analysis of fly ashes from the combustion of chips, in a small power plant, that those ashes mostly contained calcite, diopside, lime and periclase. The presence of diopside did not significantly change the behaviour of the samples when compared to the reference mortars. This fact was related with the ratio of $(\mathrm{CaO}+\mathrm{MgO}) / \mathrm{SiO}_{2}$ in those compounds that was similar to cement (Maschio et al., 2011; Matjie et al., 2008). The high content of $\mathrm{CaO}$ and $\mathrm{MgO}$ present in ashes may improve the strength resistance of the concrete or mortars with respect to the reference provided that the silica present in ashes is higher than the silica present in cement (Maschio et al., 2011; Papadakis, 2000). The presence of calcium carbonate may alter the hydration heat because it allows a 
Table 2

X-ray diffraction intensity of $\mathrm{Ca}(\mathrm{OH})_{2}$ and $\mathrm{C}_{3} \mathrm{~S}$ during hydration of cement and a blend of cement and coal-wood fly ash mixtures.

Adapted from (Tkaczewska and Małolepszy, 2009).

\begin{tabular}{|c|c|c|c|c|}
\hline \multirow[t]{3}{*}{ Sample } & \multicolumn{4}{|c|}{$\mathrm{X}$-ray diffraction intensity of (\%) } \\
\hline & \multicolumn{2}{|c|}{$\mathrm{Ca}(\mathrm{OH})_{2}\left(34.1^{\circ} 2 \theta \mathrm{Cu} \mathrm{K} \alpha\right)$} & \multicolumn{2}{|c|}{$\mathrm{C}_{3} \mathrm{~S}\left(34.4^{\circ} 2 \theta \mathrm{Cu} \mathrm{K} \alpha\right)$} \\
\hline & At 28 day & At 180 day & At 28 day & At 180 day \\
\hline Control & 100.0 & 100.0 & 100.0 & 100.0 \\
\hline $20 \%$ of cement replacement & 82.8 & 66.8 & 85.2 & 82.7 \\
\hline $40 \%$ of cement replacement & 65.8 & 35.9 & 70.2 & 64.0 \\
\hline
\end{tabular}

faster reaction of $\mathrm{C}_{3} \mathrm{~S}$ that leads to the formation of carbosilicates and/ or carboaluminates. However, it may not lead to better mechanical strength than the pure $\mathrm{C}_{3} \mathrm{~S}$. WFA has a high content of metals and during the production of construction materials it can be dissolved in water in the ageing materials (Maschio et al., 2011).

A comparison of the influence of coal-biomass blended fly ash and only coal fly ash on the cement hydration was made by (Tkaczewska and Małolepszy, 2009), in terms of unreacted $\mathrm{C}_{3}$ S content (by XRD analysis) and in terms of the estimation of cement microstructure (by SEM-EDS analysis). In terms of XRD analysis (Table 2), it was observed that the intensity of the $\mathrm{Ca}(\mathrm{OH})_{2}$ peak in the presence of coal-wood fly ash was higher than for coal fly ash mixtures, and this was due to the lower reactivity of coal-wood fly ash with $\mathrm{Ca}(\mathrm{OH})_{2}$. Mixtures with coalwood fly ash presented a lower degree of $\mathrm{C}_{3} \mathrm{~S}$ hydration in comparison to coal fly ash mixtures (Tkaczewska and Małolepszy, 2009). The scanning microscope analysis showed that the incorporation of coalwood fly ash in cement changed the content and the morphology of calcium silicate hydrates (C-S-H). The pore content of $\mathrm{C}-\mathrm{S}-\mathrm{H}$ increased and this was due to the coarse grinding of these ashes and due to its low pozzolanic activity (Tkaczewska and Małolepszy, 2009). The analysis reported a higher $\mathrm{CaO} / \mathrm{SiO}_{2}$ molar ratio of $\mathrm{C}-\mathrm{S}-\mathrm{H}$ in mixture with coalwood ash than the mixture with coal fly ash, which can be due to different degrees of polymerisation of silicate anions in mixture with coalwood fly ash. Therefore, the C-S-H is less amorphous and the permeability of water and aggressive solution to the core of the specimen of coal-wood fly ash is increased (Tkaczewska and Małolepszy, 2009).

\section{Fresh state rheological behaviour of wood fly ash concrete}

The fresh properties of wood fly ash concrete such as workability, setting time, fresh rheology and heat of hydration are discussed in the following paragraphs.

\subsection{Workability and consistency}

Some studies (Ban and Ramli, 2011; Berra et al., 2015; Coelho, 2010; Wang et al., 2008b; Yang et al., 2016) showed that the using WFA as a partial cement replacement material interferes in the workability of concrete (Table 3 ).

Slump is a measure of concrete consistency and shows the existence of variations in the uniformity of the mixtures (Neville, 1995). This characteristic and the workability are important due to the fact they are responsible for the utility and transportation of concrete (Aitcin, 2008). The slump values of concrete decrease as cement is replaced by WFA, being this decrease more significantly for higher cement replacement contents (20 and $30 \mathrm{wt} \%$ ) (Yang et al., 2016). A partial cement replacement by those ashes decreased the mix workability, and it was more distinct at the higher ash content. Several authors attributed this to the shape of the particles and the higher specific surface area of ash porous, compared to cement particles (Barathan and Gobinath, 2013; Berra et al., 2015; Shearer et al., 2011; Wang et al., 2008b). The decrease on the slump is also due to the high unburned carbon in wood ash that absorbed water, which reduced the free water content in the mixtures (Yang et al., 2016).

However, the amount of superplasticizers, need to maintain a given slump for a constant water to cement rate, increased with the increase of cement replacement by WFA. This increase was due to the ash particles' angular shape, irregular shape and high porosity and due to their high loss-on-ignition. This led to an increase in the water requirement and consequently in the high dosage of superplasticizers to maintain the same workability as the reference concrete (Abdullahi, 2006; Barathan and Gobinath, 2013; Berra et al., 2015; Kara et al., 2012; Rajamma et al., 2015; Shearer et al., 2011; Wang et al., 2008a).

\subsection{Water demand and consistency}

The cementitious materials blended with cement are less reactive than plain cement during setting and early hardening. Hence, it is important to know the amount of water needed for each mixture, because the early strength and permeability of the concrete are a function of the reactions that occurs during the early hydration of the portion of cement present in the binder (Aïtcin and Mindess, 2011). The amount of water is very important in the fresh state of concrete mainly due to the fact of controlling: the rheology of the fresh concrete, the position of the binder particles in the mixture, the initial solubility of the different ionic species of the binder, the electrical and thermal conductivity of the fresh concrete, creating the cohesion that makes concrete workable while decreasing the segregation (Aïtcin and Mindess, 2011; Neville, 1995).

The incorporation of WFA leads to an increase in the amount of water required to produce pastes with a desired consistency (Rajamma et al., 2015, 2009). Rajamma (2011) and Coelho (2010) observed interesting findings in their studies, with $10 \%$ replacement of cement by wood fly ash in the total binder's weight. The consistency and the water demand were similar to that of plain cement mixture, but with higher percentages of replacement, the water demand increased. Water demand has increased proportionately with the increase in cement replacement by biomass ashes (expressed as a percentage of the total binder's weight) (Ban and Ramli, 2011).

Wang et al. (2008c) studied the water demand of different concrete mixtures using different supplementary materials (coal fly ash classes $\mathrm{C}$ and F, sawdust and wood fly ash). They observed that all samples had similar or lower water demand than pure cement mixtures, except for wood mix. The lower water demand of carbon fly ash mixtures is an advantage over plain cement mixtures and is due to the high-temperature treatment producing less porous and finer spherical particles having a filling effect on the mixtures. This led to an increase in the fluidity of fresh concrete and reduces the water demand (Freeman et al., 1997; Lane and Best, 1982; Ravina and Mehta, 1986; Wang et al., 2008c).

A summary of the effect of WFA on the consistency and water demand of concrete can be seen in Table 4 and is explained by the physical properties of ashes. The high surface, high organic content (LOI) and irregular shape allows for adsorption of water by the ash particles in the mixing and because they are hygroscopic by nature, they lead to higher water demands and issues with consistency (Rajamma, 2011; Wang et al., 2008b).

\subsection{Fresh rheology}

Fresh rheology explains the plastic state of fresh concrete and this property has been described in various studies (Artelt and Garcia, 2008; Ban and Ramli, 2011; Cordeiro et al., 2009; Emoto and Bier, 2007; Kovler and Roussel, 2011; Maschio et al., 2011; Modolo et al., 2013; Ponikiewski and Gołaszewski, 2014; Sfikas et al., 2014; Siddique, 2004; Stark, 2011; Yammine et al., 2008). Rajamma et al. (2015) studied the rheological behaviour of mortars with $0,10,20$ and $30 \%$ wt of cement replacement by two wood fly ashes. Fresh rheology was evaluated in a 
Table 3

Wood fly ash influence on concrete workability.

\begin{tabular}{|c|c|c|c|c|c|}
\hline Application & $\%$ Of cement replacement & Influence of wood fly ash & Compared with & $\begin{array}{l}\text { Spread flow/Slump } \\
(\mathrm{mm})\end{array}$ & Ref. \\
\hline Concrete & 10,20 and $30 \% w t$ & $\begin{array}{l}\text { - wood ash to partially replace cement slightly reduced the slump } \\
\text { (by less than } 50.8 \mathrm{~mm} \text { ) }\end{array}$ & $\begin{array}{l}\text { Portland } \\
\text { cement }\end{array}$ & $\begin{array}{l}(\mathrm{w} / \mathrm{b}=0.42) \\
101.6-108\end{array}$ & $\begin{array}{l}\text { Yang et al. } \\
\text { (2016) }\end{array}$ \\
\hline Mortars & 10,20 and $30 \% w t$ & $\begin{array}{l}\text { - Up to } 10 \% \text { the consistency of mortar is not visible; } \\
\text { - above } 20 \% \text { wt the slump values decreased significantly }\end{array}$ & $\begin{array}{l}\text { Portland } \\
\text { cement }\end{array}$ & $\begin{array}{l}(\mathrm{w} / \mathrm{b}=0.55) \\
90-120 \\
(\mathrm{w} / \mathrm{b}=0.60) \\
105-150 \\
(\mathrm{w} / \mathrm{b}=0.65) \\
110-150\end{array}$ & $\begin{array}{l}\text { Rajamma et al. } \\
\text { (2015) }\end{array}$ \\
\hline Paste & 15 and $30 \% w t$ & $\begin{array}{l}\text { at a fixed } \mathrm{w} / \mathrm{b} \text { ratio, the WFA decreased the mix workability;this } \\
\text { effect was more pronounced at the higher ash content ( } 30 \mathrm{wt} . \% \text {; }\end{array}$ & $\begin{array}{l}\text { Portland } \\
\text { cement }\end{array}$ & - & $\begin{array}{l}\text { Berra et al. } \\
(2015)\end{array}$ \\
\hline Concrete & 20,30 and $40 \% w t$ & $\begin{array}{l}\text { - wood ash contributed more to workability; } \\
\text { - slump of wood ash was } 1,5-2 \text { times greater; } \\
\text { - due to wood ash particle size, shape, and chemical composition } \\
\text { - increasing on wood ash the slump values decrease; due to water } \\
\text { absorption by the ashes }\end{array}$ & Coal fly ash & $\begin{array}{l}(\mathrm{w} / \mathrm{b}=0.49) \\
20 \% \mathrm{wt}-160 \\
30 \% \mathrm{wt}-125-140 \\
40 \% \mathrm{wt}-115-145\end{array}$ & $\begin{array}{l}\text { Kara et al. } \\
(2012)\end{array}$ \\
\hline Mortar & $\begin{array}{l}25 \% \text { wt (blend of WFA + CFA, } \\
\text { with the WFA increasing on the } \\
\text { blend) }\end{array}$ & $\begin{array}{l}\text { - Wood fly ash decreased the slump values; } \\
\text { the percentage reduction in mortar flow is greater than the } \\
\text { percentage addition of WFA; } \\
\text { - However, the resulting mortar flows are still high in comparison } \\
\text { to the cement-only mix indicating the positive CFA properties } \\
\text { outweigh the negative properties of the WFA. }\end{array}$ & Coal fly ash & - & $\begin{array}{l}\text { Shearer et al. } \\
(2011)\end{array}$ \\
\hline
\end{tabular}

Viskomat PC Rheometer (Rajamma et al., 2015). The testing time was from 15 to $60 \mathrm{~min}$, depending on the ash content. The authors estimated the yield stress and the plastic viscosity from Bingham's model (Fig. 5). The authors reported that it was not possible to test this parameter on mortars with $30 \%$ of ashes, because torque was insufficient to overcome the yield stress and plastically deform the material. Another interesting result was the fact that torque increased at a constant rate directly dependent on the biomass ash fraction. The authors reported that a desirable fluidity was found when the amount of water added to the mixture was enough to fill the pores, which avoided intense interparticle friction of solid particles. This was contrary to what WFA particles do to the system as those particles tend to absorb water molecules, reducing the amount of free water and acting as a lubricant for the movement of solid particles (Rajamma et al., 2015). This leads to an increase in the particle friction and the plasticity of mixtures reduces.

As can be seen in Fig. 5, the viscosity of the different mixtures tends to decrease and the differences between the mortars were attenuated. However, the yield stress increased after $5 \mathrm{~min}$ of testing and the mortars with ashes were stiffer than cement mortar. Usually, the plastic viscosity depends on the volume of solid particles and their packing density. On the other hand, yield stress is related to the flocculation and the strength of the forces responsible for flocculation and represents the initial resistance to the flow (Senff et al., 2012, 2009; Struble and Lei, 1995).

Maschio et al. (2011) studied the influence of replacing cement by WFA (in an equivalent mass of 5, 10, 20 and $30 \mathrm{wt} \%$ ) on the rheological behaviour of mortars. The authors observed that the presence of these ashes had modifications in the rheological behaviour when compared to the reference blend. They verified that the apparent viscosity of suspensions with $30 \%$ of wood fly ash was slightly superior to that the same mixtures but with coal fly ash. They concluded that those changes were due to the presence of $\mathrm{KCl}$ and $\mathrm{K}_{2} \mathrm{SO}_{4}$ in the ashes, which led to the precipitation of gypsum and portlandite during the beginning of mix hydration. However, $10 \% w t$ of cement replacement by wood fly ash leads to better rheological properties of mortar, with lower yield stress and lower viscosity (Skripkiunas et al., 2017).

Even though, the studies presented are about mortar, similar conclusions can be taken for concrete, since the influence of wood fly ash on the fresh rheology of concrete will mostly affected by the fresh behaviour of the binder part.

\subsection{Setting times}

The initial and final setting times are significant for practical applications of cement-based materials. Those times are an indicator of the workable state of the concrete fresh mix (Al-Mulali et al., 2015). Some studies showed that the utilisation of wood fly ash blended with cement as binder delayed the cement setting and this effect increased with the increase in the level of cement substitution by ashes (Table 6) (Ban and Ramli, 2011; Rajamma et al., 2015, 2009; Wang et al., 2008c). Berra et al. (2015) observed a little retarding effect on the setting due to the substitution of cement by wood ashes. The amount of biomass affects the setting time (Table 5), and the delay in setting time is higher when it uses a higher dosage. It is known that with the increase of alkali elements and the organic matter present in ashes there is a higher absorption of water by the ashes in the mixtures and the setting times usually increase (Rajamma et al., 2009). On the other hand, if there are some materials in the mix with low sulphur content but with high potassium content, such as the WFA, the setting times tend to increase (Hewlett, 2004).

Several studies have shown that various types of WFA (alone or blended with coal fly ash) present results within the range of the results from coal fly ashes, indicating that despite the fact that wood fly ash leads to a delay in the setting times, there is no disproportionate impact on the concrete strength development (Hewlett, 2004; Ravina and Mehta, 1986; Wang et al., 2008c; Wesche, 2004).

\subsection{Heat evolution}

The heat evolution indicates the rate of the exothermic hydration reaction of concrete binder (Aitcin and Mindess, 2011; Neville, 1995). Determining the heat evolution is important to detect and record some modifications induced by the presence of WFA (Hewlett, 2004).

The evaluation of the effect of fly ashes from biomass conversion on the hydration behaviour was studied using calorimetric analysis by Rajamma et al. (2009). The authors showed that the highest temperature of hydration was observed in the sample containing only cement. The hydration process in all samples reached a steady temperature of approximately $24^{\circ} \mathrm{C}$ within 3 days. The authors observed that the hydration peak of samples with WFA was reached early than for the samples composed only with cement. They also observed that the heat of hydration decreased with the increase on the biomass ash content, indicating a reduction in the hydrating phases for the ash replaced 
cements. The authors reported that the differences observed in the hydration peak and in the hydration rate are probably influenced by the alkalis and chloride present in the WFA (Hewlett, 2004). One important observation was the influence of the amount of ashes on the heat. As the content of ashes increased, the heat of hydration decreased, thus indicating a decrease in the hydration phases in the ash replaced cements. The decrease in the heat peaks showed that the WFA influences the pastes and leads to a decrease in the hydration rate. This is related to the specific area (Hewlett, 2004) of wood fly ash but also with the influence on pastes by alkalis and chlorides present in ashes (Rajamma et al., 2009). The low heat in concrete containing WFA could be an advantage, because when the temperature gradients of concrete are large and when there are too many restraints to thermal contraction, the concrete may crack (Aitcin and Mindess, 2011).

A comparison of the influence between coal-wood fly ash and only coal fly ash (Class F) on the hydration of cement was done by (Tkaczewska and Małolepszy, 2009). They observed that the effect of fly ashes on cement hydration is variable. Moreover, for coal-wood fly ash mixtures, the induction period was longer and the heat evolution main peak was smaller than that for the coal fly ash mixtures (Tkaczewska and Małolepszy, 2009). Furthermore, a delay in cement hydration in the presence of coal-wood fly ash was reported. This led to the conclusion that some calcium ions were released into the solution. They observed that the presence of the blended ashes prolonged the induction period due to the increase of the time when the supersaturated state could be reached and similar results were verified in Fajun et al. (1985). The heat of hydration can be proportionally related with the number of nucleation sites by fly ashes for cement hydrates. It can be concluded then that the presence of coal-wood fly ashes in cement leads to a smaller nucleating site for the precipitation of hydration product (Tkaczewska and Małolepszy, 2009).

\subsection{General considerations}

Table 6 gives a summary about the influence of wood fly ash on the concrete fresh properties. As it can be seen, in general, just replacement of cement until $10 \%$ by weight of binder did not has a negative impact on the fresh properties. For the replacement higher than $10 \% \mathrm{wt}$, the impact of wood fly ash increase with the increase of wood fly ash content. The influence of wood ash in all fresh properties is due to the fact of wood ashes presents a higher particle size distribution and higher organic matter content than cement or coal fly ash, which leads to a higher absorption of water by wood fly ash during the mixing, and change the workability and consistency of mixtures. However, this negative impact, it was observed that this can be solved using chemical admixtures like, for example, a superplasticizer that allow a better workability without compromising the overall quality of the concrete.

\section{Hardened properties of wood fly ash concrete}

\subsection{Mechanical strength}

Several authors (Barbosa et al., 2013b; Berra et al., 2015; Coelho, 2010; Horsakulthai et al., 2011; Rajamma et al., 2015, 2009; Sata et al., 2007; Tkaczewska and Małolepszy, 2009; Wang et al., 2008b,c) reported the influence of using biomass ash as a partial cement replacement in the mechanical strength of hardened concrete and mortars. In these studies, it can be observed that the particle size of ashes, the level of replacement and the curing period influence the mechanical strength of concrete, and an example of those results is presented in Table 7.

Blends of WFA with coal fly ashes were incorporated by (Tkaczewska and Małolepszy, 2009). The authors found that for the early stage of curing, the compressive strength was lower than for the reference mixtures, and this was related to the delayed in the pozzolanic reaction (Tkaczewska and Małolepszy, 2009). The low values for the compressive strength for mixtures with coal-wood fly ash was due 

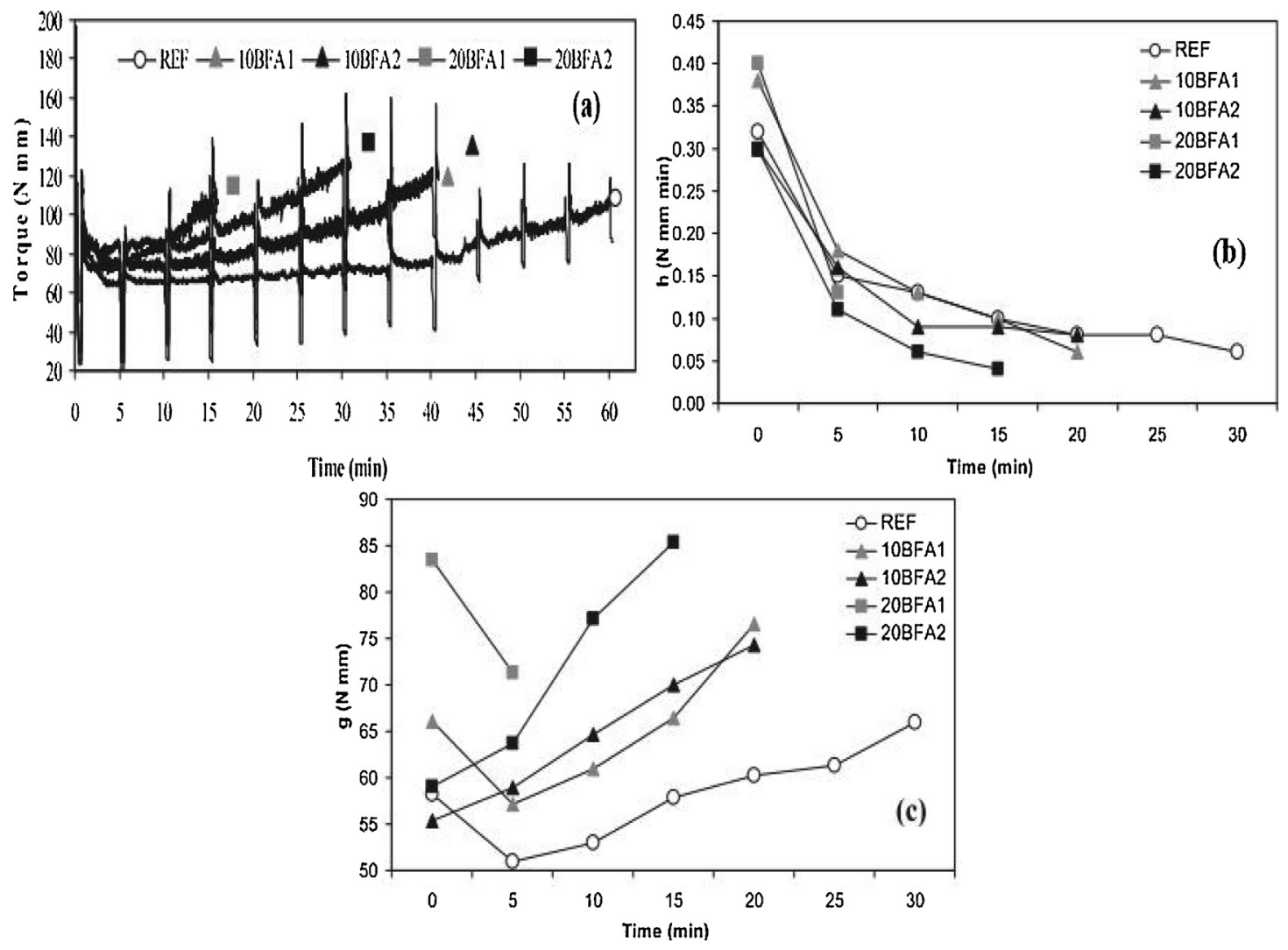

Fig. 5. Rheological behaviour for the different mortars with different percentages of cement replacement by wood fly ashes (WFA). Legend: (a) torque, (b) plastic viscosity - h, (c) yield stress variation - g (Rajamma et al., 2015).

Table 5

Setting times of cement pastes.

Adapted from Berra et al. (2015).

\begin{tabular}{lll}
\hline Mix & Initial setting time (min) & Final setting time (min) \\
\hline PC (control) & 290 & 450 \\
$15 \%$ WFA1 & 360 & 460 \\
$30 \%$ WFA1 & 350 & 490 \\
$15 \%$ WFA2 & 290 & 520 \\
$30 \%$ WFA2 & 500 & 800 \\
$15 \%$ WFA3 & 270 & 650 \\
$30 \%$ WFA3 & 620 & 960 \\
\hline
\end{tabular}

to its particles, which were coarser than coal fly ash and led to a decrease in the density of cement matrix (Tkaczewska and Małolepszy, 2009).

In Portugal, the utilisation of forest residues and woody biomass for the production of heat and power is widely used. Therefore, it is very important to understand the applicability of the ashes produced during forest residue combustion, as a cement replacement. Some studies were done using these types of ashes, are reported in Coelho, Barbosa et al. (2013b), Coelho (2010), Rajamma et al. (2009) and showed a decrease in the compressive and flexural strength with the increase in the fly ash percentage. The authors concluded that a partial replacement of cement by WFA can be done at a level of up to $20 \%$ in order to maintain an acceptable mechanical strength. However, substituting cement with $10 \%$ of WFA provided the best results for mechanical strength. Furthermore, Barbosa et al. (2013b) also studied the relationship between the curing period and the compressive strength and observed that WFA delayed the hydration process for the curing time studied (60 and 90 days) (Table 7). The authors verified that during the curing period, the concrete with a lower replacement level of cement had the highest compressive strength values.
The literature shows that for different particle sizes of ashes and for different percentages of cement replacement, the values for compressive strength change (Table 7). On the other hand, for a replacement of high content of cement by WFA, the values of compressive strength were lower than the reference mixes.

The comparison between the compressive strength of concrete for a plain cement concrete and mixes with different percentages of cement replacement by wood fly ashes, for different curing ages is shown in Fig. 6. It can be seen that the compressive strength of concrete decrease with the increase in the content of WFA as cement replacement material. These results could mean that the pozzolanic activity in wood ash is more limited to a certain extent than for example coal fly ash, due to the fact that wood fly ash has particles with large size. However, the results showed that the behaviour of wood fly ash is similar to the coal fly ash, which show the possibility of using this material as a cement replacement material on concrete without comprises the quality of concrete. Fig. 6 suggests that the best results overall were obtained with addition of wood fly ash until $20 \%$ wt of cement replacement.

\subsection{Porosity}

One of the ways to determine the open porosity of concrete is by the water absorption test. During the water absorption test, the water will occupy the outside connected empty spaces present in dry concrete. Thus, the water absorption by immersion analysis provides a measure of the open pore volume or open porosity of hardened concrete (Ganesan et al., 2008; Ottosen et al., 2016). Lessard et al. studied the effect of cement substitution by wood fly ash $(0,10,20$ and 30\%) in the water absorption and air voids of paver-compacted concrete. The authors reported that the use of WFA did not show significant changes in water absorption, with values between 3.5 and $4.3 \%$. However, a slightly increase in the water absorption with an increase in cement replacement was noted. This increase is due to the formation of a 
Table 6

General trends of wood fly ash impacts on fresh concrete properties.

\begin{tabular}{|c|c|c|}
\hline Concrete properties & Influence of fly ash & Ref. \\
\hline \multirow[t]{2}{*}{ Slump } & Wood fly ash at $10 \%$ wt replacement level does not affect the workability & Rajamma et al. (2015) \\
\hline & $\begin{array}{l}\text { The increase on \% of wood fly ash, the values of slump decrease. Due to due to wood ash particle size, } \\
\text { shape, and chemical composition }\end{array}$ & $\begin{array}{l}\text { Kara et al. (2012), Rajamma et al. (2009), Shearer } \\
\text { et al. (2011) }\end{array}$ \\
\hline \multirow[t]{2}{*}{ Water demand } & $\begin{array}{l}\text { Water demand increases with the wood fly ash content. Due to due to wood ash particle size, shape, } \\
\text { and chemical composition }\end{array}$ & $\begin{array}{l}\text { Rajamma et al. (2015), Rissanen et al. (2018), } \\
\text { Wang et al. (2008c,b) }\end{array}$ \\
\hline & Milling the wood ash minimises its impact on water demand & Rissanen et al. (2018) \\
\hline \multirow[t]{4}{*}{ Fresh Rheology } & Wood fly ash has influence on the fresh rheology & Maschio et al. (2011), Rajamma et al. (2015) \\
\hline & $\begin{array}{l}\text { Depends on wood fly ash mineral composition, its fineness, particle size distribution/granulometry and } \\
\text { amount; }\end{array}$ & Skripkiunas et al. (2017) \\
\hline & $\begin{array}{l}10 \% \text { of cement replaced by wood fly ash, leads to better rheological properties: not only lower yield } \\
\text { stress and lower viscosity }\end{array}$ & \\
\hline & $>30 \%$ of wood fly ash leads to an increase on the fresh rheology & Maschio et al. (2011) \\
\hline Setting time & $\begin{array}{l}\text { Wood fly ash lead to a retardation on the setting times does not have a disproportionately impact on } \\
\text { concrete strength development }\end{array}$ & $\begin{array}{l}\text { Hewlett (2004), Ravina and Mehta (1986), Wang } \\
\text { et al. (2008c), Wesche (2004) }\end{array}$ \\
\hline \multirow[t]{2}{*}{ Heat evolution } & $\begin{array}{l}\text { The coal-wood fly ashes retard cement hydration, prolonging the induction period and lowering the } \\
\text { heat evolution main peak more than fly ash from bituminous coal combustion. } \\
\text { For coal-wood fly ashes, the summarised heat of hydration is significantly lower than that for cement } \\
\text { without additive. The difference reaches } 21.0 \% \text { at } 28 \mathrm{~h} \text { and } 20.5 \% \text { at } 72 \mathrm{~h}\end{array}$ & Tkaczewska and Małolepszy (2009) \\
\hline & $\begin{array}{l}\text { Formulations containing lower amounts of wood fly ash hydrated faster, with a similar heat of } \\
\text { hydration to pure cement paste }\end{array}$ & Rajamma et al. (2009) \\
\hline
\end{tabular}

cementitious matrix, which was more porous and less homogeneous (Lessard et al., 2017). Similar results were found in Nagrockienè and Daugèla (2018).

Udoeyo et al. (2006) measured the water absorption capacity of concrete made with WFA obtained from wood waste burning. Wood waste fly ash of pre-treated timber of $5-30 \%$ by weight of cement was added as a supplement to the concrete mixture. They observed an increase in the water absorbed with the increase in ash content and similar results were observed in Torkaman et al. (2014). At 5\%, the water absorption content was $0.4 \%$ which increased to $1.05 \%$ at $30 \%$ of wood waste content (Udoeyo et al., 2006). It is important to mention that the values observed by the authors are far less than the maximum accepted for the construction materials (10\%) (Chowdhury et al., 2015). These variations on the results (in later curing ages) are mainly due to the decrease of hydrated compounds content and are due to latent hydration of WFA when reacting in the presence of $\mathrm{Ca}(\mathrm{OH})_{2}$ (Rajamma, 2011).

Rajamma (2011) studied the porosity and the pore diameter by mercury intrusion porosimetry (MIP). The results showed an increase in the total porosity with the increasing of WFA replacement, although the median pore diameters decreased. The mean diameter decreased due to the finer particle inclusion (since the wood fly ash was sieved at $75 \mu \mathrm{m}$ before incorporation on mortars) which acted as a better packing filling effect. However, the porosity increased due to the lesser net hydration in the WFA incorporated mortars (Rajamma, 2011). The authors reported that by the end of 720 days the differences between the samples in terms of porosity were insignificant.

Tkaczewska and Małolepszy (2009) studied the porosity of coalbiomass cement pastes using the mercury intrusion porosimetry method. The authors studied two cement replacement fractions, of 20 and $40 \%$ by mass. The utilisation of coal-biomass ash in cement increases the total porosity of pastes at 180 days as compared to the control paste (only cement as a binder). This result is endorsed to coarser fineness of the coal-wood fly ashes and to its low pozzolanic. The authors reported that this fly ash is less effective in reducing the average pore diameter and this is the result of worse packing of its coarse particles and a small amount of amorphous C-S-H resulting by the pozzolanic reaction (Chindaprasirt et al., 2005; Tkaczewska and Małolepszy, 2009).

The relation between compressive strength and porosity is presented in Fig. 7. At 28 days of curing, a polynomial relation exists between compressive strength and hardened concrete porosity, with a correlation coefficient of 0.902 . This result showed that the compressive strength is a function of porosity. Therefore, it can be seen that with the increase in the percentage of wood fly ash will result in increasing the porosity and reducing the compressive strength.

\subsection{Coefficient of air permeability}

Cheah and Ramli (2012) studied the intrinsic air permeability values of hardened mortar using an air permeability cell in accordance with the method proposed by Cabrera and Lynsdale (1988). The tests were done in mortars with different percentages of high calcium wood fly ash for two curing ages (28 and 90 days) as it can be seen in Fig. 8 . The authors reported that at 28 days there was a decrease in the degree of air permeability for mortars containing high calcium wood fly ash (HCWFA) relative to the reference mortar, and the mortars with $5 \%$ of HCWA exhibited the lowest values. The values of air permeability increased gradually with the increase in cement replacement by HCWFA. This is probably due to the dominating effect of micro-filler action of wood fly ash particles. This contributes to the refinement of pore structures of wood mortars at an early age. Furthermore, an increase in HCWA content and a corresponding reactive silica amount did not contribute to a reduction in intrinsic air permeability of mix at 28 days of curing (Cheah and Ramli, 2012).

A decrease in the air permeability on the mortars with $5-15 \%$ of high calcium WFA was also observed, but an increase in mortars with 20 and $25 \%$ of cement replacement was observed. For mortar with $5-15 \%$ of wood fly ash, there was a presence of fine factions of ashes in the aggregate-cement paste interfacial transition zone, which resulted in a significant enhancement in the quality of the zones. Therefore, degrees of continuous pores of mortar were reduced in that order that results in a lower level of mix permeability. For a higher cement replacement, dilution of cement content in the mix results in a lower rate of hydration and microstructure development of cement paste (Cheah and Ramli, 2012).

The linear regression equations were plotted (Fig. 8) for wood fly ash mortars from which the behaviour of air permeability can be interpolated. The two trend lines have positive slope indicating that with the increase in cement replacement by wood fly ash, the coefficient of air permeability increased. Being the explanation for this behaviour described in the last paragraphs. The correlation coefficients at 28 and 90 days were found to be 0.93 and 0.87 respectively.

The relation between compressive strength and the coefficient of air permeability is presented in Fig. 9. As can be seen, just at 28 days of curing, a linear relation exists between compressive strength and 

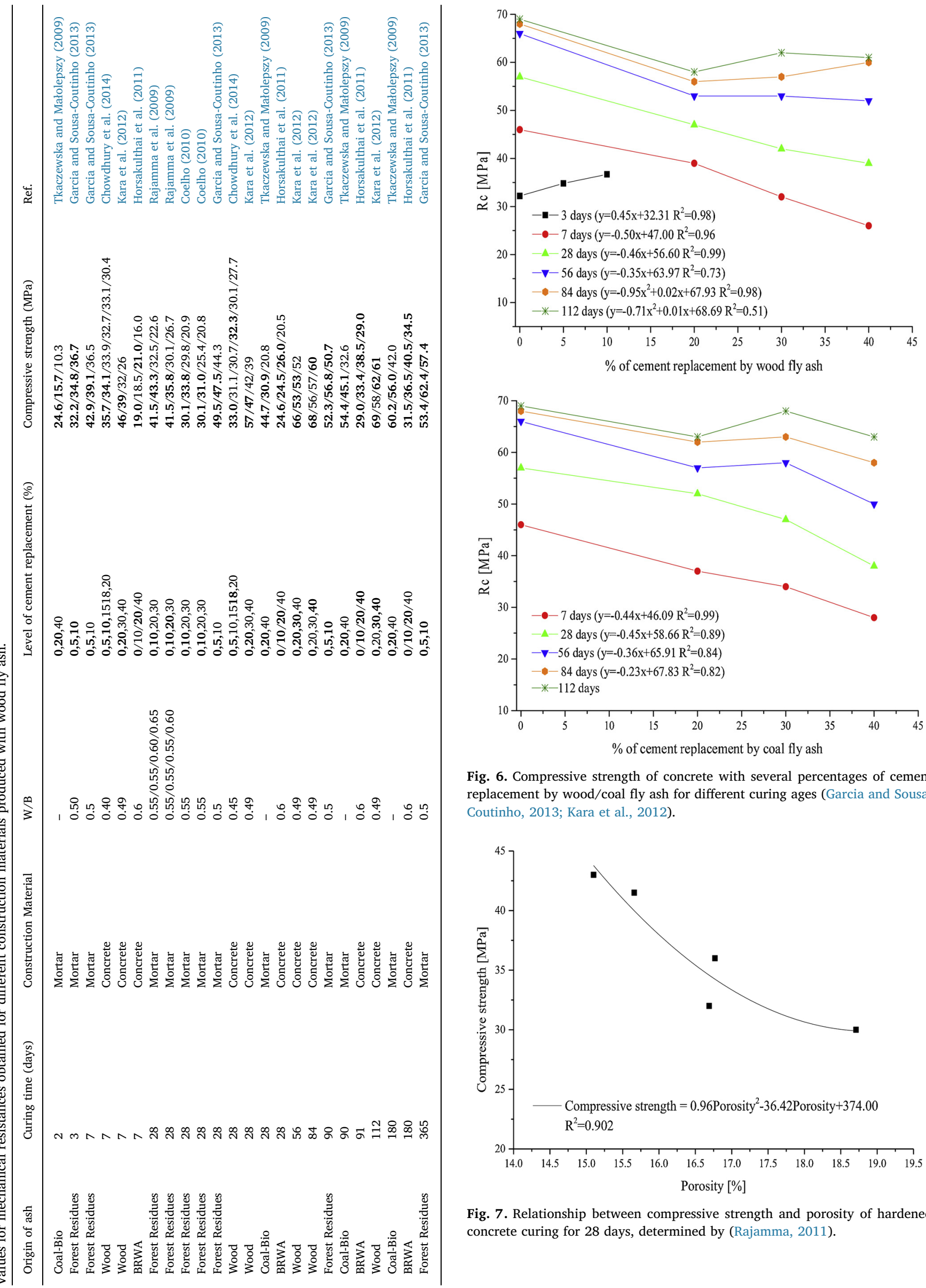

Fig. 6. Compressive strength of concrete with several percentages of cement replacement by wood/coal fly ash for different curing ages (Garcia and SousaCoutinho, 2013; Kara et al., 2012).

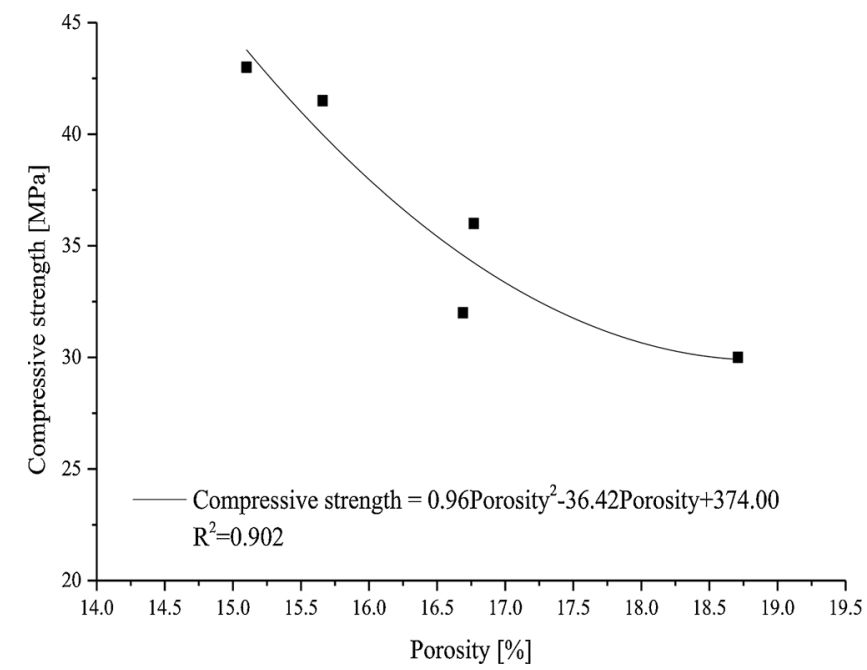

Fig. 7. Relationship between compressive strength and porosity of hardened concrete curing for 28 days, determined by (Rajamma, 2011). 


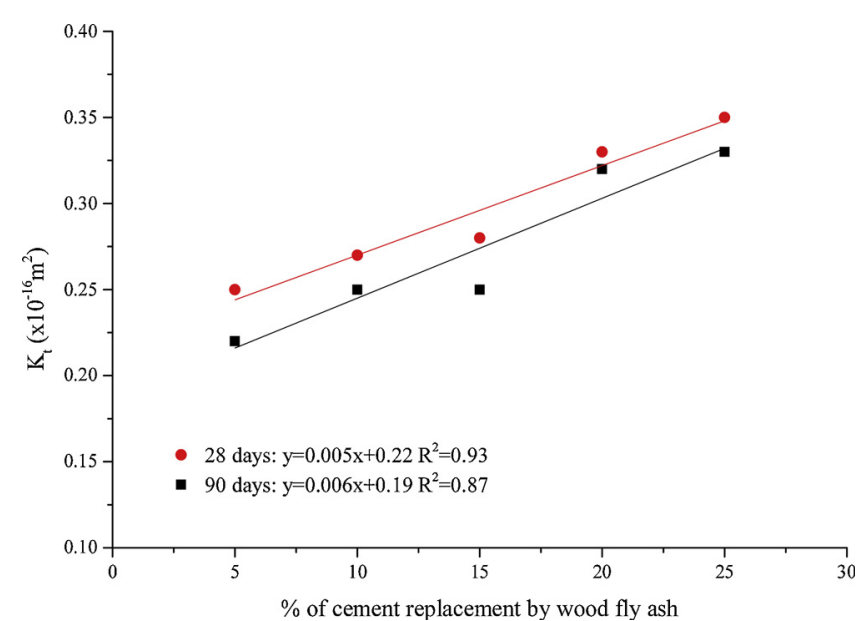

Fig. 8. Intrinsic air permeability of mortars with various wood fly ash content. Adapted from Cheah and Ramli (2012).

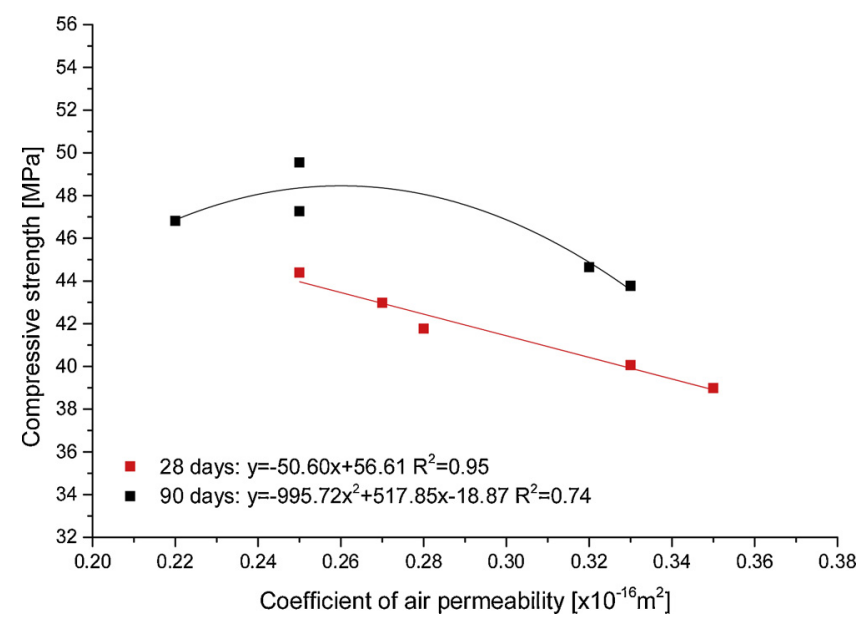

Fig. 9. Relationship between compressive strength and air permeability coefficient of hardened mortars.

hardened mortar coefficient of air permeability. For 90 days, there is a polynomial relation between these two properties. The correlation coefficient at 28 and 90 days was found to be 0.95 and 0.74 respectively. As it can be seen the negative slope is an indication that with the increase of air permeability coefficient (due to the increase on the wood fly ash content - Fig. 8) the compressive strength decreases. This was expected since it is known that a more porous concrete has less compressive strength (da Silva and de Brito, 2015; Ramezanianpour and Malhotra, 1995). Another important observation is that with the increase on the curing, the coefficient of air permeability decrease. This shows that the continuous moist curing of concrete is essential to achieve the lowest air permeability and a higher compressive strength (Parrott, 1995; Ramezanianpour and Malhotra, 1995).

Besides the study presented in this point is related with mortars, similar general conclusions can be taken for concrete, since the influence of wood fly ash is focused in the binder part and this is considered in mortar formulations. Therefore, it can be reported that in general the increase on the wood fly ash content leads to a more permeable concrete and a less resistance concrete.

\subsection{Durability properties}

\subsubsection{Electrical resistivity}

The results of the electrical resistivity are associated to the effect of the overall reduction of the pore size (Ban and Ramli, 2011;
Horsakulthai et al., 2011). Its measure is an important instrument to study the hydration reaction (Rajamma et al., 2015). The electrical resistivity of pastes with different cement substitutions by two types of WFA was studied by (Rajamma et al., 2015). The authors observed a similar behaviour for all pastes in terms of electrical resistivity. Initially, this parameter increased due to the formation of ettringite. After that, they reported a constant rate until a second stage. This second step was coincident with the final setting. The important observation was that the reference paste (only with cement) showed higher resistivity values and a faster increase upon curing when compared to the pastes with wood fly ashes. This was due to the fact of a faster setting on cement pastes. A retardation of electrical resistivity on pastes containing higher fly ash content was noted (Rajamma et al., 2015).

The electrical resistivity also gives some indications about the permeability of concrete and the probability of corrosion in reinforced concrete (Lessard et al., 2017; Velay-Lizancos et al., 2017). Lessard et al. (2017) studied the resistivity on paver-compacted concrete at 28 and 91 days of age by applying an electrical current through two electrodes attached to the concrete specimen $(\phi 100 \times 300 \mathrm{~mm}$ cylinders) ends. The results showed that WFA concrete is classified as having very low permeability, according to the ACI Committee 222 (Miyandehi et al., 2016), with values in the range of 58 and $146 \mathrm{k} \Omega \mathrm{cm}$ (Lessard et al., 2017). One important observation reported by the authors was that with the increase in the cement replacement by WFA a decrease in the electrical resistivity was noted. One of the explanations for this fact is that these concretes (with WFA) are less dense with porous cement matrix. They concluded that despite the decrease in this test, concrete with WFA is resistant to the penetration of chloride ions and aggressive agents (Lessard et al., 2017).

In general, the wood fly ashes strongly affected the evolution of electric conductivity at the early ages (Velay-Lizancos et al., 2017), but with the increase on the curing of concrete the wood fly ash concrete are classified as very low, in terms of permeability.

\subsubsection{Resistance to chloride penetration and diffusion}

One important issue related to the durability of concrete structures is the ingress of chloride ions, which can lead to the corrosion of steel reinforcement (Chindaprasirt et al., 2007; Wesche, 2004). Steel reinforcement corrosion can occur when a certain threshold value of chloride concentration in the interface between the reinforcing bars and the cementitious matrix is exceeded causing the disruption of the steel's protective passive film. This value is dependent on the type of material and environmental factors, such as water/cement ratio, curing conditions and the testing date (Alonso et al., 2000; Chindaprasirt et al., 2007; Thomas, 1996; Wang et al., 2008b).

The literature shows that the introduction of pozzolanic materials improves protection against chloride-induced corrosion of steel reinforcement, mainly because it reduces the permeability and diffusivity of concrete (Bijen, 1996; Chindaprasirt et al., 2007). Wang et al. (2008b) studied the rapid chloride permeability of concrete with wood fly ash, coal fly ash type C and type F and blends (80\% of coal ash type C or coal ash type F and $20 \%$ of biomass) according to ASTM C $1202-$ 91. The authors observed that WFA mixes had similar charges to those that passed through the pure cement mix, the class $\mathrm{C}$ fly ash had a lower permeability than WFA mixes, class $\mathrm{F}$ fly ash had the lowest permeability and the blend coal type C-biomass ash presents permeability between the mixes of their resource (WFA and class C CFA). The authors reported that due to the fact of wood fly ash having a larger particle size and higher alkalis, wood mixes have the highest permeability among all fly ash concrete (the blend ashes had permeability values between the concretes only with wood ashes and the concrete with only coal fly ashes). Class $\mathrm{C}$ has higher equivalent alkali than Class $\mathrm{F}$, and this was the reason for a higher permeability in Class $\mathrm{C}$ concrete than Class F. Moreover, similar results were found in (Alhozaimy et al., 1996). These results can also be due to the fact that the aluminates presented in the coal fly ash adsorb the chlorides to the surfaces of fly 
ash particles forming chloroaluminates, which leads to a decrease in free chloride. In other words, coal fly ash has a greater chloride binding capacity (Jensen and Prattt, 1989).

Similar results were observed by (Omran et al., 2018; Pavoine et al., 2014), concrete with wood fly ash presents lower permeability than a conventional concrete. But it was observed that with the increase on curing age, the permeability of wood fly ash concrete decreased. Leading to the conclusion that with highly finer particles, lower density, and higher pozzolanic reactivity. The wood fly ash increased the volume of binder matrix and refined the pore network that made the microstructure of concrete denser and less permeable (Omran et al., 2018).

The binding capacity of chlorides in hydrated cement paste affects the transport rate of chlorides in concrete and the amount of chlorides required to initiate active corrosion (Sandberg, 1999). The aluminate and ferrite phases present in the binder are able to bind chlorides by forming chloroaluminate hydrates and chloroferrite hydrates, but the latter are considered less important because they have high solubility and slow rate of formation (Jensen and Prattt, 1989). Coal fly ash cement blends have a greater chloride binding capacity when compared with normal cement, mainly because of the adsorption of chlorides to the surfaces of fly ash particles (Worthington et al., 1988) and the chlorides are incorporated into the aluminate-rich pozzolanic products of fly ash cement blends, removing a large quantities of chlorides from the aqueous phases (Jensen and Prattt, 1989). Some studies using other biomass fly ashes than wood (Chalee et al., 2013; Cruz-Yusta et al., 2011) showed that WFA has similar behaviour to coal fly ashes. However, it is not very well described in the literature if WFA presents a similar chloride binding capacity to coal fly ash or similar to those biomass fly ashes (rice husk and olive fly ash).

\subsubsection{Carbonation}

Carbonation is the chemical reaction between the $\mathrm{CO}_{2}$ present in the air with the calcareous components of hardened cement paste (Wesche, 2004). Fly ashes react with $\mathrm{Ca}(\mathrm{OH})_{2}$ to form similar $\mathrm{C}-\mathrm{S}-\mathrm{H}$ phases as the hydrates. The calcium hydroxide is consumed and the alkalinity of material decreases, but this consumption depends on the amount of reactive silica present in fly ash and on the duration of hydration (Wesche, 2004). Ramos et al. (2013) studied the resistance to carbonation of mortars with 10 and $20 \%$ of WFA as a cement replacement. The authors reported that the carbonation depth for blended cement mortars was greater than for the plain cement mortar. The carbonation increased with the increase in the biomass ash content, which is similar to the trend of other pozzolanic materials. They suggested that this result is due to $\mathrm{CH}$ reduction and consequent $\mathrm{pH}$ reduction. Cheah and Ramli (2012) studied the carbonation depth of mortar containing high calcium wood fly ash as a cement replacement (5-25\%). The results showed that $5 \%$ of wood fly ash contributed to the reduction in the average depth of the carbonation zone compared to mortar made only with cement. For the other cement substitutions, the carbonation depth was higher than for the control mortar and varied proportionately with the cement replacement level. This behaviour is consistent with the results achieved by (Batt and Garg, 2017; Khan and Lynsdale, 2002).

At higher levels of cement replacement by WFA, there are more amorphous silica minerals for a reaction with $\mathrm{Ca}(\mathrm{OH})_{2}$ produced from the hydration reaction of cement, forming calcium silicate hydrated gel leaving less quantity of free $\mathrm{Ca}(\mathrm{OH})_{2}$ in hardened mix (Cheah and Ramli, 2012). Therefore, less quantity of $\mathrm{CO}_{2}$ is needed for the reaction with $\mathrm{Ca}(\mathrm{OH})_{2}$ to produce $\mathrm{CaCO}_{3}$ (Neville, 1995). The mortars with $5 \%$ of WFA had less carbonation depth, most probably due to low pozzolanic activity and due to an inadequate quantity of amorphous silica and low permeability of the mix. The authors confirmed this conclusion by the chemical analysis of the 5\% wood fly ash mortar (Cheah and Ramli, 2012).

It is known that the replacement of cement by high volume of coal fly ash increases the carbonation of concrete (Hussain et al., 2017).

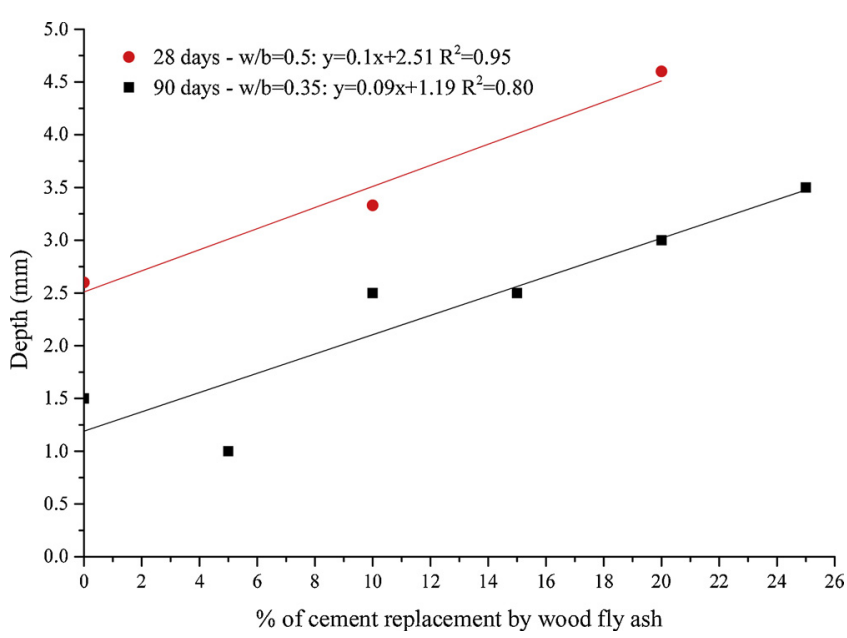

Fig. 10. Relationship between carbonation depth and percentage of cement replacement by WFA.

Usually, this is due to the consumption of $\mathrm{Ca}(\mathrm{OH})_{2}$ in the pozzolanic reaction even before the initiation of carbonation (Hussain et al., 2017). In the blended concretes, the reactions which involve un-hydrated constituents and calcium hydrate, which result in the calcium carbonate and hydrated silica as products of the reaction are also important (Richardson, 2003). The hydrated calcium silicate is dissolved when the $\mathrm{pH}$ value and the calcium ions concentration drops due to the consumption of $\mathrm{Ca}(\mathrm{OH})_{2}$. The monosulphate and ettringite decomposes at $\mathrm{pH}$ of 11.6 and 10.6, respectively. Then, the calcium ions bind to $\mathrm{CaCO}_{3}$ leaving only some ions in the form of silica gel (Lagerblad, 2005). This leads to a lower $\mathrm{CaO} / \mathrm{SiO}_{2}$ content in concrete. To compensate these issues, some authors (Filho, 2002; Reis et al., 2014) use a commercial hydrate lime (calcium hydroxide) in the binder composition to provide more alkalinity to the concrete solution achieving good results. Using WFA at a lower concentration improves in terms of carbonation resistance, as shown in Cheah and Ramli (2012), and this could be due to the fact that WFA gives extra alkalinity (an extra calcium content) to the concrete mixture.

The relation between carbonation depth and the percentage of cement replaced by wood fly ash is reported in Fig. 10, for two curing ages with two water/binder (w/b) ratios. At the two ages a linear relation exists between the content of wood fly ash and the carbonation depth, being the correlation coefficient 0.95 and 0.80 for 28 and 90 days, respectively. It can be observed that in general, with the increase in the percentage of WFA as cement replacement will result in increasing on the carbonation depth of concrete while carbonation depth decrease with curing age and increase with w/b ratio. It can be observed that the slopes of \%WFA-depth relationship at 28 and 90 days were almost equal, but at 90 days a slightly lower tendency was noted. This shows that the rate of increase of carbonation depth with wood fly ash percentage seems to be higher at early ages. This may be attributed to curing, since a longer curing leads to a higher hydration of cement, a higher pozzolanic effect of WFA, a smaller porosity, a reduction on permeability and therefore to a more compact microstructure, which leads to a lower velocity of carbonation penetration for later ages (Teixeira et al., 2019; Thomas and Matthews, 1992).

\subsubsection{Freezing and thawing resistance}

Only a few studies showed results about the behaviour of freezing and thawing resistance of concrete with the incorporation of WFA. Wang et al. (2008b) studied the durability of WFA concrete in terms of freezing and thawing resistance according to ASTM C666. The results showed a less or equal weight loss of all concrete than the control plain cement concrete. This mainly suggested that the impact on freezing and thawing behaviour is reduced and these results are in accordance with 
other studies (Helmuth, 1987; Wesche, 2004). The authors reported that the weight gain phenomena should be related to the water gain of samples in the test machine that loses a great deal of moisture during the 26-day exposure to air to be compensated by the ASTM standard of 2 days in a fog room prior to testing (Wang et al., 2008b).

The authors (Wang et al., 2008b) showed that the presence of fly ash does not appear to have a significant impact on the freezing and thawing behaviour with a proper amount of air entraining agent (AEA), however these ashes have a greater impact on the amount of AEA needed to meet the specifications of the ASTM standard. The results allow the authors to divide the concrete mixes into two different groups: (1) CFA Class F and WFA - Class F had a minimum AEA requirement and (2) WFA, WFA - Class C, CFA Class C and pure cement has the lowest AEA requirement of the study developed. These results show that with the similar amount of air content all ashes perform well and similarly in terms of the freezing and thawing resistance to that of the pure cement concrete.

The study of the effect of WFA on the freezing and thawing resistance of concrete was done by Thomas et al. (1999). In this study, the resistance was evaluated by the changes in the relative dynamic modulus, pulse velocity and change in length. The wood fly ashes were used as 5, 8 and $12 \%$ of cement replacement (Chowdhury et al., 2015; Siddique, 2012). The authors did not report a significant effect of the freeze-thaw cycles (300 cycles) on the relative dynamic modulus of concrete mixes. Therefore, they concluded that the incorporation of WFA did not affect the relative modulus. Otherwise, no significant effect was observed on pulse velocity, and the results of the values were similar to those obtained for the reference plain concrete (Chowdhury et al., 2015; Siddique, 2012; Thomas et al., 1999). Similar results were observed by (Nagrockienè and Daugèla, 2018; Omran et al., 2018).

The main conclusion that can be taken is the incorporation of wood fly ash on concrete does not affect the ability of concrete to resist to freezing and thawing.

\subsubsection{Acid and sulphate resistance}

The harmful action that involves sulphate ions is defined by a sulphate attack (Neville, 2004). The utilisation of pozzolans and cement as binder in concrete revealed an improvement in the resistance against the sulphate attack (Hossain et al., 2016; Huang et al., 2016; Sahoo et al., 2017).

There is no information about the effect of several types of WFA in the sulphate resistance of concrete,

The acid resistance of a wood blended cement concrete mix was studied by (Aye and Oguchi, 2011). Two sets of concrete specimens with mix proportions of 1:2:4 and water to binder ratio of 0.65 were manufactured. The first one contained only cement as the binder and the other contained $15 \%$ of cement replacement by wood fly ash. The hardened specimens were immersed in $20 \%$ of nitric acid. A loss in the mass of specimens was observed, but after 9 weeks a slight increase on the mass, was observed due to the absorption of water. After 10 weeks of testing, an absorption decrease in mass was registered for both types of concrete. However, the loss of mass was more significant in concretes made only with cement (Aye and Oguchi, 2011; Chowdhury et al., 2015).

\subsection{Alkali silica reaction}

Inside the concrete some internal expansive phenomenon can occur, namely alkali aggregate reaction (AAR) (Esteves, 2010). One particular reaction, the alkali-silica reaction (ASR), is the origin of several problems in concrete structures (Esteves, 2010).

The hydroxyl ions react with the potassium and sodium ions presented in the interstitial solution of concrete. The reaction allows the formation of an alkaline hygroscopic gel (Ichikawa, 2009; Reis and Silva, 1996), which absorbs water and expands. The expansion and water absorption originate some internal stresses in concrete and this promotes its cracking. This leads to a decrease in the mechanical resistances and in the durability of concrete (Esteves, 2010).

The alkali-silica reaction has been studied by several authors (Fernandes et al., 2004; Garcia-Diaz et al., 2006; Hou et al., 2004; Reis and Silva, 1996). All the studies pointed out three mandatory conditions for that reaction to occur: (i) existence of reactivity aggregates, (ii) high alkalinity on interstitial solution and (iii) high humidity (Esteves, 2010; Esteves et al., 2012; Reis and Silva, 1996). This reaction does not affect the concrete if one or more of those conditions were not verified. Several other factors can play an important role such as: the porosity of concrete, the external temperature and the alkalis introduced by mineral additives or chemical admixtures or water (Davraz and Gündüz, 2008; Esteves et al., 2012; Ramachandran, 1998).

The reaction results from cement reactivity with the badly crystallised silica aggregates This silica has a disorderly structure, and for that reason is non-stable in an alkaline environment mainly due to its high superficial area (Esteves, 2010). In comparison, the crystalline silica has an ordered structure, involving atoms or ions which occur in an orderly and periodic form in space. This silica is more stable in alkaline environments, mainly because its superficial area is lower (Esteves, 2010).

The presence of alkalis in cement is a result of each raw material, and these alkalis are in sulphate, silicate and aluminate forms (Esteves, 2010; Fernandes et al., 2004). These compounds are presented in the cement surface or inside its structure (Esteves, 2010). The alkalis present in the surface are more available to react or suffer dissolution during the cement hydration. The alkalinity of concrete can be increased, not only by the cement, but also through the mixing water (Esteves, 2010; Reis and Silva, 1996).

Esteves et al. (2012) studied the incorporation of 20 and $30 \%$ of WFA from Portuguese industrial plants, in mortars. The main aim was to test the ability of the wood fly ash to resist damage by an alkali silica reaction. They observed that mortar containing 20 and $30 \% \mathrm{wt}$ of WFA resisted to the alkali silica reaction. They found a significant reduction in the expansion of mortars, and this expansion decreased with the increase of cement replacement content. The substitution of cement by WFA improves the mitigation of ASR (Esteves et al., 2012; Wang and Baxter, 2007), even better than when it is used coal fly ash as a cement replacement material. This is due to the fact of WFA having more alkalinity than coal fly ashes (Wang and Baxter, 2007).

As it can be seen in Fig. 11, there is a linear relation $\left(R^{2}>0.99\right)$ between the expansion and the \% of cement replacement by wood fly ashes, for the two studied wood fly ash. In general, it can be verified that with the increase of the wood fly ash content on the mixture leads to a production of a more resistant to ASR concrete.

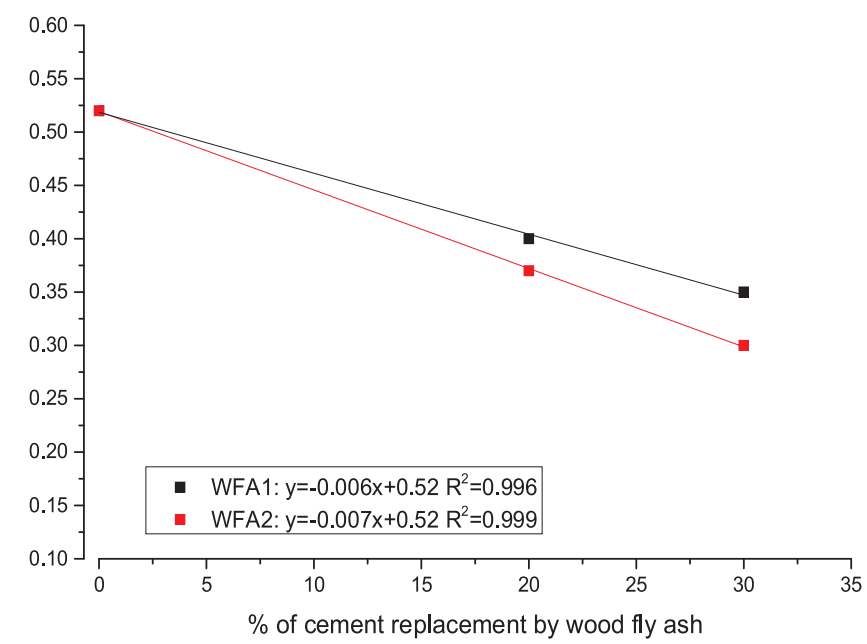

Fig. 11. Relationship between expansion by ASR reaction and percentage of cement replacement by WFA. 


\subsection{Sustainability of wood fly ash concrete}

The utilisation of wood fly ash as a cement replacement material in construction industry can be an excellent environmental choice. Cement production is one of the main man activities that generate high amounts of $\mathrm{CO}_{2}$ emissions, where each tonne of cement produced generates about $950 \mathrm{~kg}$ of $\mathrm{CO}_{2}$ (Israde-alc, 2019; Shi et al., 2011). Therefore, wood fly ash utilisation on this industry save costs for ash disposal (Fuller et al., 2018; Lisbeth et al., 2016), decrease energy requirement (for cement clinker production) and decrease greenhouse gas emission (by cement clinker substitution) (Ukrainczyk et al., 2016).

The utilisation of wood fly ashes as a cement replacement material can guarantee the sustainability of construction industry. Life cycle analysis (LCA) is often used to evaluate the environmental performance of materials (Hossain et al., 2017; Wang et al., 2016; Xu and Shi, 2018; Yang et al., 2017). LCA can estimate the potential impact on humans and on the environment and can also identify areas with improvement potential (Celik et al., 2015; Teixeira et al., 2019). Understanding the environmental impact of concrete with wood fly ash is related to the study of economic and ecological characteristics of materials (WBCSD and IEA, 2009).

Teixeira et al. (2016) studied the environmental performance of concrete with 20,49 and $60 \%$ wood fly ash as a cement substituent. The wood fly ash was originated by the combustion of forest residues on a pulp and paper industry. The authors made a comparison with a conventional concrete and with concrete with same cement replacement percentages but with coal fly ash. It was studied several environmental indicators, like as: Global Warming, Ozone Layer Depletion, Acidification Potential, Eutrophication Potential, Formation Potential of Tropospheric ozone and Abiotic Depletion Potential of Fossil Resources. They observed that with the increase on the wood fly ash percentage, the values of the environmental indicators decreased. Concluding that concretes made with wood fly ash had a better environmental performance than concrete with coal fly ash or/and with cement. Same authors made a different study and they observed similar results (Teixeira et al., 2019). The utilisation of blended cements on concrete production lead to several environmental advantages that include reduced $\mathrm{CO}_{2}$ emissions, reduces fuel consumption and lead to material valorisation of the supplementary cementing materials (Naik and Moriconi, 2005).

Kara et al. (2012) estimated the energy consumption of concrete with cement substitution by wood fly ashes. They reported that the use of wood fly ash as a construction material is beneficial in terms of landfills and reducing $\mathrm{CO}_{2}$ emissions to atmosphere. The embodied energy, which is the total amount of non-renewable primary energy required for all the direct and indirect processes related to the creation of building, its maintenance and end-life, is very low on its used wood fly ashes, being lower than other types of biomass fly ashes and coal fly ash (González-kunz et al., 2017).

Besides the quantifiable benefits of LCA, wood fly ash concrete also shows a good performance in terms of ecotoxicological properties. Barbosa et al. (2013b) studied the influence of WFA on the leaching and ecotoxicological properties of concrete, using water or marine eluates. The $\mathrm{pH}$ of eluates with water was around 10 . This indicates the release of some oxides from concrete to water, but this finding was the same for concrete with cement and/or WFA. However, when marine eluates were used, the $\mathrm{pH}$ did not change. The results showed low concentrations of chemical elements on the eluates, using fresh water or a marine solution. Similar results were found in (Siddique, 2012). The emission of chemical elements was similar or lower than those verified for the reference concrete. In terms of ecotoxicological levels, it was observed that the ecotoxic levels were reduced and were similar to the plain cement concrete.

\section{Conclusions}

Wood fly ash has been used as a partial cement substitute, as a pozzolanic material. It presents several compositions and properties because, this ash is influenced by several parameters, such as combustion technology, operation conditions and the place where it is collected. Wood fly ash has more variety in terms of composition and inorganic material content than coal fly ash. However, the similarity to the chemical and physical properties of Class $\mathrm{C}$ fly ash shows that it can be used as a partial cement replacement.

The utilisation of WFA affects the workability of concrete, because it results in an increase in the amount of water required to a desirable consistency, an opposite behaviour to when coal fly ash is used. The consistency is also affected by the particle size of ashes and by the amount of partial cement replacement. Moreover, the initial and final setting times of fresh mixture concrete are retarded when WFA is incorporated. As a result of the changes in the workability and consistency promoted by the incorporation of WFA in concrete, an influence on the rheological properties of concrete results.

The heat of hydration of concrete binders is influenced by fly ash and it was observed that an increase in the amount of wood fly ash leads to a decrease in heat. This showed that the hydration phase in materials with cement replaced by wood fly ash also decreases too. In this case, the decrease on the heat could be an advantage, because it could prevent the occurrence of a cracking phenomenon.

Using WFA slows down the hydration reactions and provokes some modifications in the rheological behaviour and microstructure of concrete. WFA leads to an increase in the open porosity and a decrease in the air permeability of the hardened concrete. However, some electric resistivity tests showed that mortars with wood ashes are classified as having very low permeability. There was no decrease in the non-hydrated cement and portlandite amount and an increase in the C-S-H gel present in the concrete did not occur for a long period of curing, when compared to the reference concrete.

The study on the mechanical strength of concrete with wood fly ash showed that this parameter is dependent on the percentage of cement replacement and the curing time. In general, WFA addition decreases the compressive strength. However, good results can be achieved.

In terms of durability, some authors observed an increase in the chlorides penetration but others observed a decrease in this parameter when WFA was used. The decrease in this parameter was observed when wood fly ash was used mixed with another pozzolanic material as a cement replacement, and in this case the synergetic behaviour of the two materials was better than when wood fly ash is only used. Furthermore, in terms of carbonation, it can be concluded that only when a small amount of wood fly ash is used in construction materials, there is more resistance to carbonation than in mixtures made only with cement as binder or better resistance than coal fly ash concrete.

Wood fly ash leads to concretes with a more resistance to alkalisilica reactions. On the other hand, the presence of WFA on concrete does not have a different behaviour to the reference concrete in terms of freezing and thawing resistance, neither a significant influence in its leaching. However, in terms of environmental performance, wood fly ash concrete presents better results than plain cement concrete.

In short, this work shows that it is possible to use WFA as a partial cement replacement at least with similar results to coal fly ash, the most traditional pozzolanic material, in terms of durability and quality of concrete. Therefore, by using WFA, at an industrial level of concrete production, some issues can be solved, such as the decrease in energy and raw material consumption related to cement production. Moreover, a more sustainable option in wood fly ash management can be applied.

\section{Acknowledgemtns}

The authors wish to thank the Portuguese Foundation for Science and Technology (FCT) and the Eco-Construction and Rehabilitation Doctoral Programme for supporting the PhD scholarship (reference PD/ BD/52661/2014). This work was also financed by FEDER funds through the Competitivity Factors Operational Programme - COMPETE 
and by national funds through FCT - Foundation for Science and Technology within the scope of the project POCI-01 - 0145-FEDER 007633 and through the Regional Operational Programme CENTRO2020 within the scope of the project CENTRO-01 - 0145FEDER - 000006.

\section{References}

Abdullahi, M., 2006. Characteristics of wood ASH/OPC concrete. Leonardo Electron. J. Pract. Technol. 9-16.

Ahmaruzzaman, M., 2010. A review on the utilization of fly ash. Prog. Energy Combust. Sci. 36, 327-363. https://doi.org/10.1016/j.pecs.2009.11.003.

Aitcin, P.-C., 2008. Binders for durable and sustainable concrete. In: Taylor, F. (Ed.), Modern Concrete Technology. Taylor \& Francis, London and New York. https://doi. org/10.1017/CBO9781107415324.004.

Aïtcin, P.C., Mindess, S., 2011. Sustainability of Concrete, 1st ed. Spon Press.

Al-Mulali, M.Z., Awang, H., Abdul Khalil, H.P.S., Aljoumaily, Z.S., 2015. The incorporation of oil palm ash in concrete as a means of recycling: a review. Cem. Concr. Compos. 55, 129-138. https://doi.org/10.1016/j.cemconcomp.2014.09.007.

Alhozaimy, A., Soroushian, P., Mirza, F., 1996. Effects of curing conditions and age on chloride permeability of fly ash mortar. Int. Concr. Abstr. Portal - Mater. J. 93, 87-95. https://doi.org/10.14359/9800.

Alonso, C., Andrade, C., Castellote, M., Castro, P., 2000. Chloride threshold values to depassivate reinforcing bars embedded in a standardized OPC mortar. Cem. Concr. Res. 30, 1047-1055. https://doi.org/10.1016/S0008-8846(00)00265-9.

Aranda Usón, A., López-Sabirón, A.M., Ferreira, G., Llera Sastresa, E., 2013. Uses of alternative fuels and raw materials in the cement industry as sustainable waste management options. Renew. Sustain. Energy Rev. 23, 242-260. https://doi.org/10. 1016/j.rser.2013.02.024.

Artelt, C., Garcia, E., 2008. Impact of superplasticizer concentration and of ultra-fine particles on the rheological behaviour of dense mortar suspensions. Cem. Concr. Res. 38, 633-642. https://doi.org/10.1016/j.cemconres.2008.01.010.

ASTM C618-15, 2015. Standard Specification for Coal Fly Ash and Raw or Calcined Natural Pozzolan for Use in Concrete.

Aye, T., Oguchi, C.T., 2011. Resistance of plain and blended cement mortars exposed to severe sulfate attacks. Constr. Build. Mater. 25, 2988-2996. https://doi.org/10. 1016/j.conbuildmat.2010.11.106.

Ban, C.C., Ramli, M., 2011. The implementation of wood waste ash as a partial cement replacement material in the production of structural grade concrete and mortar: an overview. Resour. Conserv. Recycl. 55, 669-685. https://doi.org/10.1016/j. resconrec.2011.02.002.

Barathan, S., Gobinath, B., 2013. Evaluation of wood ash as a partial replacement to cement. Int. J. Sci. Eng. Technol. Res. 2, 2009-2013.

Barbosa, R., Dias, D., Lapa, N., Lopes, H., Mendes, B., 2013a. Chemical and ecotoxicological properties of size fractionated biomass ashes. Fuel Process. Technol. 109, 124-132. https://doi.org/10.1016/j.fuproc.2012.09.048.

Barbosa, R., Lapa, N., Dias, D., Mendes, B., 2013b. Concretes containing biomass ashes: mechanical, chemical, and ecotoxic performances. Constr. Build. Mater. 48, 457-463. https://doi.org/10.1016/j.conbuildmat.2013.07.031.

Batt, A.S., Garg, A., 2017. Partial replacement of wood ash with ordinary portland cement and foundry sand as fine aggregate. J. Civ. Environ. Eng. 07, 1-5. https://doi.org/10. 4172/2165-784X.1000272.

Benhelal, E., Zahedi, G., Shamsaei, E., Bahadori, A., 2013. Global strategies and potentials to curb CO2 emissions in cement industry. J. Clean. Prod. 51, 142-161. https://doi. org/10.1016/j.jclepro.2012.10.049.

Berra, M., Mangialardi, T., Paolini, A.E., 2015. Reuse of woody biomass fly ash in cementbased materials. Constr. Build. Mater. 76, 286-296. https://doi.org/10.1016/j. conbuildmat.2014.11.052.

Berry, E.E., Malhotra, V.M., 1980. Fly ash for use in concrete - a critical review. Int. Concr. Abstr. Portal - J. Proc. 77, 59-73. https://doi.org/10.14359/6991.

Bijen, J., 1996. Benefits of slag and fly ash. Constr. Build. Mater. 10, 309-314. https:// doi.org/10.1016/0950-0618(95)00014-3.

Cabrera, J.G., Lynsdale, C.J., 1988. A new gas permeameter for measuring the permeability of mortar and concrete. Mag. Concr. Res. 40, 177-182.

Camões, A., Aguiar, B., Jalali, S., 2005. Estimating compressive strength of concrete by mortar testing. INCOS 05 International Conference on Concrete for Structures Coimbra.

Capablo, Jensen, J., Pedersen, P.A., Hjuler, K.H., Nikolaisen, K., Backman, L., Frandsen, R., 2009. Ash properties of alternative biomass. Energy Fuels 23, 1965-1976.

Celik, K., Meral, C., Petek Gursel, A., Mehta, P.K., Horvath, A., Monteiro, P.J.M., 2015. Mechanical properties, durability, and life-cycle assessment of self-consolidating concrete mixtures made with blended portland cements containing fly ash and limestone powder. Cem. Concr. Compos. 56, 59-72. https://doi.org/10.1016/j cemconcomp.2014.11.003.

Chalee, W., Sasakul, T., Suwanmaneechot, P., Jaturapitakkul, C., 2013. Utilization of rice husk-bark ash to improve the corrosion resistance of concrete under 5-year exposure in a marine environment. Cem. Concr. Compos. 37, 47-53. https://doi.org/10.1016/ j.cemconcomp.2012.12.007.

Chaunsali, P., Uvegi, H., Osmundsen, R., Laracy, M., Poinot, T., Ochsendorf, J., Olivetti, E., 2018. Mineralogical and microstructural characterization of biomass ash binder. Cem. Concr. Compos. 89, 41-51.

Cheah, C.B., Ramli, M., 2012. Mechanical strength, durability and drying shrinkage of structural mortar containing HCWA as partial replacement of cement. Constr. Build.
Mater. 30, 320-329. https://doi.org/10.1016/j.conbuildmat.2011.12.009.

Chindaprasirt, P., Chotithanorm, C., Cao, H.T., Sirivivatnanon, V., 2007. Influence of fly ash fineness on the chloride penetration of concrete. Constr. Build. Mater. 21, 356-361. https://doi.org/10.1016/j.conbuildmat.2005.08.010.

Chindaprasirt, P., Jaturapitakkul, C., Sinsiri, T., 2005. Effect of fly ash fineness on compressive strength and pore size of blended cement paste. Cem. Concr. Compos. 27, 425-428. https://doi.org/10.1016/j.cemconcomp.2004.07.003.

Chowdhury, S., Maniar, A., Suganya, O.M., 2014. Strength development in concrete with wood ash blended cement and use of soft computing models to predict strength parameters. J. Adv. Res. 6, 907-913. https://doi.org/10.1016/j.jare.2014.08.006.

Chowdhury, S., Mishra, M., Suganya, O., 2015. The incorporation of wood waste ash as a partial cement replacement material for making structural grade concrete: an overview. Ain Shams Eng. J. 6, 429-437. https://doi.org/10.1016/j.asej.2014.11.005.

Coelho, A.M.S.L., 2010. Gestão de Cinzas produzidas em centrais de cogeração operadas com biomassa (Management of ashes produced in biomass co-generation industries). Master Thesis. Departamento de Ambiente e Ordenamento. Universidade de Aveiro.

Cordeiro, G.C., Toledo Filho, R.D., Tavares, L.M., Fairbairn, E.M.R., 2009. Ultrafine grinding of sugar cane bagasse ash for application as pozzolanic admixture in concrete. Cem. Concr. Res. 39, 110-115. https://doi.org/10.1016/j.cemconres.2008.11. 005 .

Cordeiro, G.C., Toledo Filho, R.D., Tavares, L.M., Fairbairn, E.M.R., 2008. Pozzolanic activity and filler effect of sugar cane bagasse ash in Portland cement and lime mortars. Cem. Concr. Compos. 30, 410-418. https://doi.org/10.1016/j. cemconcomp.2008.01.001.

Cruz-Yusta, M., Mármol, I., Morales, J., Sánchez, L., 2011. Use of olive biomass fly-ash in the preparation of environmental friendly mortars. Environ. Sci. Technol. 45, 6991-6996.

da Silva, P.R., de Brito, J., 2015. Experimental study of the porosity and microstructure of self-compacting concrete (SCC) with binary and ternary mixes of fly ash and limestone filler. Constr. Build. Mater. 86, 101-112. https://doi.org/10.1016/j. conbuildmat.2015.03.110.

Dahl, O., Nurmesniemi, H., Manskinen, K., Pöykiö, R., 2012. Forest fertilizer properties of the bottom ash and fly ash from a large-sized (115MW) industrial power plant incinerating wood-based biomass residues. J. Univ. Chem. Technol. Metall. 47, 43-52.

Dahl, O., Nurmesniemi, H., Pöykiö, R., Watkins, G., 2010. Heavy metal concentrations in bottom ash and fly ash fractions from a large-sized (246 MW) fluidized bed boiler with respect to their Finnish forest fertilizer limit values. Fuel Process. Technol. 91, 1634-1639. https://doi.org/10.1016/j.fuproc.2010.06.012.

Dahl, O., Nurmesniemi, H., Pöykiö, R., Watkins, G., 2009. Comparison of the characteristics of bottom ash and fly ash from a medium-size (32 MW) municipal district heating plant incinerating forest residues and peat in a fluidized-bed boiler. Fuel Process. Technol. 90, 871-878. https://doi.org/10.1016/j.fuproc.2009.04.013.

Davidsson, K.O., Steenari, B., Eskilsson, D., 2007. Kaolin addition during biomass combustion in a 35 MW circulating fluidized-bed boiler. Energy Fuels 1959-1966.

Davraz, M., Gündüz, L., 2008. Reduction of alkali silica reaction risk in concrete by natural (micronised) amorphous silica. Constr. Build. Mater. 22, 1093-1099. https:// doi.org/10.1016/j.conbuildmat.2007.03.002.

Demirbas, A., 2005. Potential applications of renewable energy sources, biomass combustion problems in boiler power systems and combustion related environmental issues. Prog. Energy Combust. Sci. 31, 171-192. https://doi.org/10.1016/j.pecs. 2005.02.002.

Demis, S., Tapali, J.G., Papadakis, V.G., 2014. An investigation of the effectiveness of the utilization of biomass ashes as pozzolanic materials. Constr. Build. Mater. 68, 291-300. https://doi.org/10.1016/j.conbuildmat.2014.06.071.

Eliche-Quesada, D., Felipe-Sesé, M.A., López-Pérez, J.A., Infantes-Molina, A., 2017. Characterization and evaluation of rice husk ash and wood ash in sustainable clay matrix bricks. Ceram. Int. 43, 463-475. https://doi.org/10.1016/j.ceramint.2016.09. 181.

Emoto, T., Bier, T.A., 2007. Rheological behavior as influenced by plasticizers and hydration kinetics. Cem. Concr. Res. 37, 647-654. https://doi.org/10.1016/j. cemconres.2007.01.009.

EN 450-1, 2012. Norma Portuguesa, Cinzas volantes para betão, Parte 1: definição, especificações e critérios de conformidade. (Portuguese Norm, Fly ash concrete, Part 1: Definition, specifications and conformity criteria). Instituto Português da Qualidade. Instituto Português da Qualidade.

Esteves, T.C.B., 2010. Uso de cinzas volantes da queima de biomassa na mitigação da RAS (Use of fly ash from biomass combustion in ASR mitigation). Master Thesis. Departamento de Engenharia Cerâmica e Vidro, Universidade de Aveiro.

Esteves, T.C., Rajamma, R., Soares, D., Silva, A.S., Ferreira, V.M., Labrincha, J.A., 2012. Use of biomass fly ash for mitigation of alkali-silica reaction of cement mortars. Constr. Build. Mater. 26, 687-693. https://doi.org/10.1016/j.conbuildmat.2011.06. 075.

Fairbairn, E.M.R., Americano, B.B., Cordeiro, G.C., Paula, T.P., Toledo Filho, R.D., Silvoso, M.M., 2010. Cement replacement by sugar cane bagasse ash: CO2 emissions reduction and potential for carbon credits. J. Environ. Manag. 91, 1864-1871. https://doi.org/10.1016/j.jenvman.2010.04.008.

Fajun, W., Grutzeck, M.W., Roy, D.M., 1985. The retarding effects of fly ash upon the hydration of cement pastes: the first 24 hours. Cem. Concr. Res. 15, 174-184. https:// doi.org/10.1016/0008-8846(85)90024-9.

Fernandes, I., Noronha, F., Teles, M., 2004. Microscopic analysis of alkali-aggregate reaction products in a 50-year-old concrete. Mater. Charact. 53, 295-306. https://doi. org/10.1016/j.matchar.2004.08.005.

Filho, J.H., 2002. Efeitos da adição de cal hidratada sobre a permeabilidade ao oxigênio e absorção capilar de concreto com alto teores de adições minerais. (Effect of hydrate lime addition on the oxygen permeability and capilarity absorption on high volume additions concre). Universidade Federal de Santa Maria. 
Freeman, E., Gao, Y.-M., Hurt, R., Suuberg, E., 1997. Interactions of carbon-containing fly ash with commercial air-entraining admixtures for concrete. Fuel 76, 761-765. https://doi.org/10.1016/S0016-2361(96)00193-7.

Fuller, A., Stegmaier, M., Schulz, N., Menke, M., Schellhorn, H., Knödler, F., Maier, J., Scheffknecht, G., 2018. Use of wood dust fly ash from an industrial pulverized fue facility for rendering. Constr. Build. Mater. 189, 825-848. https://doi.org/10.1016/j conbuildmat.2018.09.016.

Ganesan, K., Rajagopal, K., Thangavel, K., 2008. Rice husk ash blended cement: assessment of optimal level of replacement for strength and permeability properties of concrete. Constr. Build. Mater. 22, 1675-1683. https://doi.org/10.1016/j. conbuildmat.2007.06.011.

Garcia-Diaz, E., Riche, J., Bulteel, D., Vernet, C., 2006. Mechanism of damage for the alkali-silica reaction. Cem. Concr. Res. 36, 395-400. https://doi.org/10.1016/j. cemconres.2005.06.003.

Garcia, M.D.L., Sousa-Coutinho, J., 2013. Strength and durability of cement with fores waste bottom ash. Constr. Build. Mater. 41, 897-910. https://doi.org/10.1016/j. conbuildmat.2012.11.081.

Girón, R.P., Ruiz, B., Fuente, E., Gil, R.R., Suárez-Ruiz, I., 2013. Properties of fly ash from forest biomass combustion. Fuel 114, 71-77. https://doi.org/10.1016/j.fuel.2012.04. 042

González-kunz, R.N., Pineda, P., Bras, A., Morillas, L., 2017. Plant biomass ashes in cement-based building materials. Feasibility as eco-efficient structural mortars and grouts. Sustain. Cities Soc. 31, 151-172. https://doi.org/10.1016/j.scs.2017.03.001.

Helmuth, R.A., 1987. Fly ash in cement and concrete. Portl. Cem. Assoc.

Hewlett, P.C., 2004. Lea's Chemistry of Cement and Concrete, 4th ed. Elsevier Science \& Technology Books.

Horsakulthai, V., Phiuvanna, S., Kaenbud, W., 2011. Investigation on the corrosion resistance of bagasse-rice husk-wood ash blended cement concrete by impressed voltage. Constr. Build. Mater. 25, 54-60. https://doi.org/10.1016/j.conbuildmat.2010 06.057.

Hossain, M.M., Karim, M.R., Hasan, M., Hossain, M.K., Zain, M.F.M., 2016. Durability of mortar and concrete made up of pozzolans as a partial replacement of cement: a review. Constr. Build. Mater. 116, 128-140. https://doi.org/10.1016/j.conbuildmat. 2016.04.147.

Hossain, U., Sun, C., Lo, I.M.C., Cheng, J.C.P., 2017. Comparative LCA on using waste materials in the cement industry: a Hong Kong case study. Resour. Conserv. Recycl. 120, 199-208. https://doi.org/10.1016/j.resconrec.2016.12.012.

Hou, X., Struble, L.J., Kirkpatrick, R.J., 2004. Formation of ASR gel and the roles of C-S-H and portlandite. Cem. Concr. Res. 34, 1683-1696. https://doi.org/10.1016/ cemconres.2004.03.026.

Huang, C.H., Lin, S.K., Chang, C.S., Chen, H.J., 2013. Mix proportions and mechanical properties of concrete containing very high-volume of Class F fly ash. Constr. Build. Mater. 46, 71-78. https://doi.org/10.1016/j.conbuildmat.2013.04.016.

Huang, Q., Wang, C., Luo, C., Yang, C., Luo, Y., Xie, H., 2016. Effect of mineral admixtures on sulfate resistance of mortars under electrical field. Adv. Cem. Res. 29, 45-53. https://doi.org/10.1680/jadcr.16.00063.

Hussain, S., Bhunia, D., Singh, S.B., 2017. Comparative study of accelerated carbonation of plain cement and fly-ash concrete. J. Build. Eng. 10, 26-31. https://doi.org/10. 1016/j.jobe.2017.02.001.

Ichikawa, T., 2009. Alkali-silica reaction, pessimum effects and pozzolanic effect. Cem. Concr. Res. 39, 716-726. https://doi.org/10.1016/j.cemconres.2009.06.004.

Illikainen, M., Tanskanen, P., Kinnunen, P., Körkkö, M., Peltosaari, O., Wigren, V., Österbacka, J., Talling, B., Niinimäki, J., 2014. Reactivity and self-hardening of fly ash from the fluidized bed combustion of wood and peat. Fuel 135, 69-75. https:/ doi.org/10.1016/j.fuel.2014.06.029.

Israde-alc, I., 2019. Cleaner production of one-part white geopolymer cement using pretreated wood biomass ash and diatomite. J. Clean. Prod. 209, 1420-1428. https:// doi.org/10.1016/j.jclepro.2018.11.137.

Worthington, J.C., Bonner, D.G., Nowell, D.V., 1988. Influence of cement chemistry on chloride attack of concrete. Mater. Sci. Technol. 4, 305-313. https://doi.org/10. 1179/mst.1988.4.4.305.

Jensen, H., Prattt, P.L., 1989. The binding of chloride ions by pozzolanic product in fly ash cement blends. Adv. Cem. Res. 2, 121-129. https://doi.org/10.1680/adcr.1989. 2.7.121.

Kara, P., Korjakins, A., Stokmanis-Blaus, V., 2012. Evaluation of properties of concrete incorporating ash as mineral admixtures. Constr. Sci. 13, 17-25. https://doi.org/10. 2478/v10311-012-0003-0.

Khan, A.A., Jonga, W., de Jansensb, P.J., Spliethoff, H., 2009. Biomass combustion in fluidized bed boilers: potential problems and remedies. Fuel Process. Technol. 90, 21-50. https://doi.org/10.1016/j.fuproc.2008.07.012.

Khan, M.I., Lynsdale, C.J., 2002. Strength, permeability, and carbonation of high-performance concrete. Cem. Concr. Res. 32, 123-131. https://doi.org/10.1016/S00088846(01)00641-X

Koukouzas, N., Hämäläinen, J., Papanikolaou, D., Tourunen, A., Jäntti, T., 2007. Mineralogical and elemental composition of fly ash from pilot scale fluidised bed combustion of lignite, bituminous coal, wood chips and their blends. Fuel 86, 2186-2193. https://doi.org/10.1016/j.fuel.2007.03.036.

Kovler, K., Roussel, N., 2011. Properties of fresh and hardened concrete. Cem. Concr. Res. 41, 775-792. https://doi.org/10.1016/j.cemconres.2011.03.009.

Lagerblad, B., 2005. Carbon Dioxide Uptake During Concrete Life Cycle - State of the Art, Swedish Cement and Concrete Research Institute. Swedish Cement and Concrete Research Institute, Stockholm.

Lane, R., Best, J.F., 1982. Properties and use of fly ash in portland cement concrete. Int. Concr. Abstr. Portal - Concr. Int. 4, 81-92.

Lessard, J.-M., Omran, A., Tagnit-Hamou, A., Gagne, R., 2017. Feasibility of using biomass fly and bottom ashes to produce RCC and PCC. J. Mater. Civ. Eng. 29, 1-12.
https://doi.org/10.1061/(ASCE)MT.1943-5533.0001796.

Liao, C., Wu, C., Yan, Y., 2007. The characteristics of inorganic elements in ashes from a 1 MW CFB biomass gasification power generation plant. Fuel Process. Technol. 88, 149-156. https://doi.org/10.1016/j.fuproc.2005.06.008.

Lisbeth, M., Østergaard, E., Erland, P., Marie, G., 2016. Wood Ash Used as Partly Sand and/or Cement Replacement in Mortar. https://doi.org/10.2495/SDP-V11-N5-781791.

Loo, S., Van Koppejan, J., 2012. The Handbook of Biomass Combustion \& Co-firing. Earthscan.

Mahmoudkhani, M., Richards, T., Theliander, H., 2007. Sustainable use of biofuel by recycling ash to forests: treatment of biofuel ash. Environ. Sci. Technol. 41, 4118-4123.

Maresca, A., Hyks, J., Astrup, T.F., 2017. Recirculation of biomass ashes onto forest soils: ash composition, mineralogy and leaching properties. Waste Manag. 70. https://doi. org/10.1016/j.wasman.2017.09.008.

Maresca, A., Krüger, O., Herzel, H., Adam, C., Kalbe, U., Astrup, T.F., 2019. Influence of wood ash pre-treatment on leaching behaviour, liming and fertilising potential. Waste Manag. 83, 113-122. https://doi.org/10.1016/j.wasman.2018.11.003.

Maschio, S., Tonello, G., Piani, L., Furlani, E., 2011. Fly and bottom ashes from biomass combustion as cement replacing components in mortars production: rheological behaviour of the pastes and materials compression strength. Chemosphere 85, 666-671. https://doi.org/10.1016/j.chemosphere.2011.06.070.

Matjie, R.H., Li, Z., Ward, C.R., French, D., 2008. Chemical composition of glass and crystalline phases in coarse coal gasification ash. Fuel 87, 857-869. https://doi.org/ 10.1016/j.fuel.2007.05.050

Miller, B., Dugwell, D., Kandiyoti, R., 2006. The fate of trace elements during the cocombustion of wood-bark with waste. Energy Fuels 20, 520-531. https://doi.org/10. 1021/ef058013r.

Miyandehi, B.M., Feizbakhsh, A., Yazdi, M.A., Liu, Q.F., Yang, J., Alipour, P., 2016. Performance and properties of mortar mixed with nano-CuO and rice husk ash. Cem. Concr. Compos. 74, 225-235. https://doi.org/10.1016/j.cemconcomp.2016.10.006.

Modolo, R.C.E., Ferreira, V.M., Tarelho, L.A., Labrincha, J.A., Senff, L., Silva, L., 2013. Mortar formulations with bottom ash from biomass combustion. Constr. Build. Mater. 45, 275-281. https://doi.org/10.1016/j.conbuildmat.2013.03.093.

Nagrockienè, D., Daugèla, A., 2018. Investigation into the properties of concrete modified with biomass combustion fly ash. Constr. Build. Mater. 174, 369-375. https://doi. org/10.1016/j.conbuildmat.2018.04.125.

Naik, T.R., Moriconi, G., 2005. Environmental-friendly durable concrete made with recycled materials for sustainable concrete construction. CANMET/ACI Int. Symp. Sustain. Dev. Cem. Concr. 1-13.

Neville, A., 2004. The confused world of sulfate attack on concrete. Cem. Concr. Res. 34 1275-1296. https://doi.org/10.1016/j.cemconres.2004.04.004.

Neville, A.M., 1995. Properties of Concrete, 4th ed. Pitman, London.

Nochaiya, T., Wongkeo, W., Chaipanich, A., 2010. Utilization of fly ash with silica fume and properties of Portland cement-fly ash-silica fume concrete. Fuel 89, 768-774. https://doi.org/10.1016/j.fuel.2009.10.003.

Obernberger, I., 2009. Possibilities of ash utilisation from biomass combustion plants. 17th European Biomass Conference \& Exhibition. Hamburg, Germany.

Omran, A., Soliman, N., Xie, A., Davidenko, T., Tagnit-hamou, A., 2018. Field trials with concrete incorporating biomass-fly ash. Constr. Build. Mater. 186, 660-669. https:// doi.org/10.1016/j.conbuildmat.2018.07.084.

Ottosen, L.M., Jensen, P., Kirkelund, G.M., 2016. Wood ash used as partly sand and/or cement replacement in mortar. Proceedings of the 8th International Conference on Waste Management and the Environment (Waste) 781-790. https://doi.org/10. 2495/SDP-V11-N5-781-791.

Papadakis, V.G., 2000. Effect of fly ash on Portland cement systems. Part II. High-calcium fly ash. Cem. Concr. Res. 30, 1647-1654. https://doi.org/10.1016/S0008-8846(00) 00388-4.

Parrott, L.J., 1995. Influence of cement type and curing on the drying and air permeability of cover concrete. Mag. Concr. Res. 47, 103-111. https://doi.org/10.1680/ macr.1995.47.171.103.

Pavoine, A., Harbec, D., Chaussadent, T., Tagnit-Hamou, A., Divet, L., 2014. Impact of alternative cementitious material on the mechanical and transfer properties of concrete. ACI Mater. J. 3, 251-261. https://doi.org/10.14359/51686828.

Pettersson, A., Åmand, L.-E., Steenari, B.-M., 2008. Leaching of ashes from co-combustion of sewage sludge and wood-Part II: The mobility of metals during phosphorus extraction. Biomass Bioenergy 32, 236-244. https://doi.org/10.1016/j.biombioe.2007. 09.006.

Pitman, R.M., 2006. Wood ash use in forestry - a review of the environmental impacts. Forestry 79, 563-588. https://doi.org/10.1093/forestry/cpl041.

Ponikiewski, T., Gołaszewski, J., 2014. The effect of high-calcium fly ash on selected properties of self-compacting concrete. Arch. Civ. Mech. Eng. 14, 455-465. https:// doi.org $/ 10.1016 / \mathrm{j}$.acme. 2013.10.014.

Rajamma, R., 2011. Incorporação de cinzas volantes de biomassa em materiais cimentíceos (Biomass fly ash incorporation in cement based materials). PhD Thesis. Departamento de Engenharia Cerêmica e do Vidro. Universidade de Aveiro.

Rajamma, R., Ball, R.J., Tarelho, L.A.C., Allen, G.C., Labrincha, J.A., Ferreira, V.M., 2009 Characterisation and use of biomass fly ash in cement-based materials. J. Hazard. Mater. 172, 1049-1060. https://doi.org/10.1016/j.jhazmat.2009.07.109.

Rajamma, R., Labrincha, J., Ferreira, V.M., 2012. Alkali activation of biomass fly ash metakaolin blends. Fuel 98, 265-271. https://doi.org/10.1016/j.fuel.2012.04.006.

Rajamma, R., Senff, L., Ribeiro, M.J., Labrincha, J.A., Ball, R.J., Allen, G.C., Ferreira, V.M., 2015. Biomass fly ash effect on fresh and hardened state properties of cement based materials. Compos. Part B 77, 1-9. https://doi.org/10.1016/j.compositesb. 2015.03.019.

Ramachandran, V.S.S., 1998. Alkali-aggregate expansion inhibiting admixtures. Cem. 
Concr. Compos. 20, 149-161. https://doi.org/10.1016/S0958-9465(97)00072-3.

Ramezanianpour, A.A., Malhotra, V.M., 1995. Effect of curing on the compressive strength, resistance to chloride-ion penetration and porosity of concretes incorporating slag, fly ash or silica fume. Cem. Concr. Compos. 17, 125-133. https:// doi.org/10.1016/0958-9465(95)00005-W.

Ramos, T., Matos, A.M., Sousa-Coutinho, J., 2013. Mortar with wood waste ash: mechanical strength carbonation resistance and ASR expansion. Constr. Build. Mater. 49, 343-351. https://doi.org/10.1016/j.conbuildmat.2013.08.026.

Ravina, D., Mehta, P.K., 1986. Properties of fresh concrete containing large amounts of fly ash. Cem. Concr. Res. 16, 227-238. https://doi.org/10.1016/0008-8846(86) 90139-0.

Reis, M.O.B., Silva, A.S., 1996. Recomendações gerais para prevenir a deterioração do betão por reacção álcalis sílica. In: LNEC (Ed.), Betão Estrutural 1996-6 Encontro Nacional Sobre Estruturas Pré-Esforçadas, Lisboa.

Reis, R., Malheiro, R., Camões, A., Ribeiro, M., 2014. Carbonation resistance of high volume fly ash concrete. Key Eng. Mater. 634, 288-299. https://doi.org/10.4028/ www.scientific.net/KEM.634.288.

Richardson, M.G., 2003. Fundamentals of Durable Reinforced Concrete, Modern Concrete Technology. Taylor \& Francis.

Rissanen, J., Ohenoja, K., Kinnunen, P., Romagnoli, M., Illikainen, M., 2018. Milling of peat-wood fly ash: effect on water demand of mortar and rheology of cement paste. Constr. Build. Mater. 180, 143-153. https://doi.org/10.1016/j.conbuildmat.2018. 05.014.

Rubio-Hernández, F.J., Velázquez-Navarro, J.F., Ordónez-Belloc, L.M., 2012. Rheology of concrete: a study case based upon the use of the concrete equivalent mortar. Mater. Des. https://doi.org/10.1617/s11527-012-9915-1.

Ruiz, B., Girón, R.P., Suárez-Ruiz, I., Fuente, E., 2017. From fly ash of forest biomass combustion (FBC) to micro-mesoporous silica adsorbent materials. Process Saf. Environ. Prot. 105, 164-174. https://doi.org/10.1016/j.psep.2016.11.005.

Sabet, F.A., Libre, N.A., Shekarchi, M., 2013. Mechanical and durability properties of self consolidating high performance concrete incorporating natural zeolite, silica fume and fly ash. Constr. Build. Mater. 44, 175-184. https://doi.org/10.1016/j conbuildmat.2013.02.069.

Sahoo, S., Das, B.B., Mustakim, S., 2017. Acid, alkali, and chloride resistance of concrete composed of low-carbonated fly ash. J. Mater. Civ. Eng. 29, 1-12. https://doi.org/10. 1061/(ASCE)MT.1943-5533.0001759.

Sandberg, P., 1999. Studies of chloride binding in concrete exposed in a marine environment. Cem. Concr. Res. 29, 473-477. https://doi.org/10.1016/S0008-8846(98) 00191-4.

Sarabèr, A., Haasnoot, K., 2012. Recycling of biomass ashes in The Netherlands. Ash Utilisation. pp. 2012.

Sata, V., Jaturapitakkul, C., Kiattikomol, K., 2007. Influence of pozzolan from various byproduct materials on mechanical properties of high-strength concrete. Constr. Build. Mater. 21, 1589-1598. https://doi.org/10.1016/j.conbuildmat.2005.09.011.

Senff, L., Hotza, D., Lucas, S., Ferreira, V.M., Labrincha, J.A., 2012. Effect of nano-SiO2 and nano-TiO2 addition on the rheological behavior and the hardened properties of cement mortars. Mater. Sci. Eng. A 532, 354-361. https://doi.org/10.1016/j.msea. 2011.10.102.

Senff, L., Labrincha, J.A., Ferreira, V.M., Hotza, D., Repette, W.L., 2009. Effect of nanosilica on rheology and fresh properties of cement pastes and mortars. Constr. Build. Mater. 23, 2487-2491. https://doi.org/10.1016/j.conbuildmat.2009.02.005.

Sfikas, I.P., Badogiannis, E.G., Trezos, K.G., 2014. Rheology and mechanical characteristics of self-compacting concrete mixtures containing metakaolin. Constr. Build. Mater. 64, 121-129. https://doi.org/10.1016/j.conbuildmat.2014.04.048.

Shearer, C.R., Yeboah, N., Kurtis, K.E., Burns, S.E., 2011. The Early Age Behavior of Biomass Fired and Co-fired Fly Ash in Concrete. World of Coal Ash (WOCA). Denver, CO, USA.

Shi, C., Jiménez, A.F., Palomo, A., 2011. New cements for the 21st century: the pursuit of an alternative to Portland cement. Cem. Concr. Res. 41, 750-763. https://doi.org/10. 1016/j.cemconres.2011.03.016.

Siddique, R., 2012. Utilization of wood ash in concrete manufacturing. Resour. Conserv. Recycl. 67, 27-33. https://doi.org/10.1016/j.resconrec. 2012.07.004.

Siddique, R., 2004. Performance characteristics of high-volume Class F fly ash concrete. Cem. Concr. Res. 34, 487-493. https://doi.org/10.1016/j.cemconres.2003.09.002.

Singh, S., Ram, L.C., Masto, R.E., Verma, S.K., 2011. A comparative evaluation of minerals and trace elements in the ashes from lignite, coal refuse, and biomass fired power plants. Int. J. Coal Geol. 87, 112-120. https://doi.org/10.1016/j.coal.2011. 05.006.

Skripkiunas, G., Macijauskas, M., Nagrockienė, D., 2017. The influence of biomass fly ash on the plasticizing effects in cement pastes. Proc. Eng. 172, 1015-1022. https://doi. org/10.1016/j.proeng.2017.02.152.

Stark, J., 2011. Recent advances in the field of cement hydration and microstructure analysis. Cem. Concr. Res. 41, 666-678. https://doi.org/10.1016/j.cemconres.2011. 03.028.

Steenari, B.-M., Karlfeldt Fedje, K., 2010. Addition of kaolin as potassium sorbent in the combustion of wood fuel - effects on fly ash properties. Fuel 89, 2026-2032. https:// doi.org/10.1016/j.fuel.2010.02.006.

Steenari, B.-M., Lindqvist, O., 1997. Stabilisation of biofuel ashes for recycling to forest soil. Biomass Bioeneroy 13,39-50.

Steenari, B., Karlsson, L.G., Lindqvist, O., 1999a. Evaluation of the leaching characteristics of wood ash and the influence of ash agglomeration. Biomass Bioenergy 16, 119-136.

Steenari, B., Schelander, S., Lindqvist, O., 1999b. Chemical and leaching characteristics of ash from combustion of coal, peat and wood in a 12 MW CFB - a comparative study. Fuel 78, 249-258.

Struble, L.J., Lei, W.G., 1995. Rheological changes associated with setting of cement paste. Adv. Cem. Based Mater. 2, 224-230. https://doi.org/10.1016/1065-7355(95) 90041-1.

Tarelho, L.A.C., Coelho, A.M.S.L., Teixeira, E.R., Rajamma, R., Ferreira, V.M., 2011. Characteristics of ashes from two portuguese biomass co-generation plants. 19th European Biomass Conference \& Exhibition 6-10.

Tarelho, L.A.C., Teixeira, E.R., Silva, D.F.R., Modolo, R.C.E., Labrincha, J.A., Rocha, F., 2015. Characteristics of distinct ash flows in a biomass thermal power plant with bubbling fluidised bed combustor. Energy 90, 387-402. https://doi.org/10.1016/j energy.2015.07.036.

Tarelho, L.A.C., Teixeira, E.R., Silva, D.F.R., Modolo, R.C.E., Silva, J.J.F., 2012 Characteristics, management and applications of ashes from thermochemical conversion of biomass to energy. World Bioenergy 2012, Conference Exhibition on Biomass for Energy Jonkopin, Sweden.

Teixeira, E.R., Mateus, R., Camões, A., Branco, F.G., 2019. Quality and durability properties and life-cycle assessment of high volume biomass fly ash mortar. Constr. Build. Mater. 197, 195-207. https://doi.org/10.1016/J.CONBUILDMAT.2018.11.173.

Teixeira, E.R., Mateus, R., Camões, A.F., Bragança, L., Branco, F.G., 2016. Comparative environmental life-cycle analysis of concretes using biomass and coal fly ashes as partial cement replacement material. J. Clean. Prod. 112, 2221-2230. https://doi. org/10.1016/j.jclepro.2015.09.124.

Teixeira, E.R., Tarelho, L.A.C., Sequeira, M.C.E., Santos, C.E.C., Matos, M.A.A., 2012. Characteristics of co-combustion of sewage sludge with forest biomass in bubbling fluidized bed. World Bioenergy 2012, Conference Exhibition on Biomass for Energy Jonkopin.

Teixeira, E.R., Tarelho, L.A.C., Silva, T.C.S.R., Silva, D.F.R., Modolo, R.C.E., 2013. Physical-chemical characteristics of ash flows in a biomass thermal power plant. 21st European Biomass Conference and Exhibition Copenhagen.

Thomas, M., 1996. Chloride thresholds in marine concrete. Cem. Concr. Res. 26, 513-519.

Thomas, M.D.A., Matthews, J.D., 1992. Carbonation of fly ash concrete. Mag. Concr. Res. 44, 217-228. https://doi.org/10.1680/macr.1992.44.160.217.

Thomas, M.D.A., Shehata, M.H., Shashiprakash, S.G., Hopkins, D.S., Cail, K., 1999. Use of ternary cementitious systems containing silica fume and fly ash in concrete. Cem. Concr. Res. 29, 1207-1214. https://doi.org/10.1016/S0008-8846(99)00096-4.

Tkaczewska, E., Małolepszy, J., 2009. Hydration of coal-biomass fly ash cement. Constr. Build. Mater. 23, 2694-2700. https://doi.org/10.1016/j.conbuildmat.2008.12.018.

Tkaczewska, E., Mróz, R., Łój, G., 2012. Coal-biomass fly ashes for cement production of CEM II/A-V 42.5R. Constr. Build. Mater. 28, 633-639. https://doi.org/10.1016/j. conbuildmat.2011.10.022.

Torkaman, J., Ashori, A., Sadr Momtazi, A., 2014. Using wood fiber waste, rice husk ash, and limestone powder waste as cement replacement materials for lightweight concrete blocks. Constr. Build. Mater. 50, 432-436. https://doi.org/10.1016/j. conbuildmat.2013.09.044.

Tosti, L., van Zomeren, A., Pels, J.R., Comans, R.N.J., 2018. Technical and environmental performance of lower carbon footprint cement mortars containing biomass fly ash as a secondary cementitious material. Resour. Conserv. Recycl. 134, 25-33. https://doi. org/10.1016/j.resconrec.2018.03.004.

Udoeyo, F.F., Inyang, H., Young, D.T., Oparadu, E.E., 2006. Potential of wood waste ash as an additive in concrete. J. Mater. Civ. Eng. 18, 605-611. https://doi.org/10.1061/ (ASCE)0899-1561(2006)18:4(605).

Ukrainczyk, N., Vrbos, N., Koenders, E.A.B., 2016. Reuse of woody biomass ash waste in cementitious materials. Chem. Biochem. Eng. Q. 30, 137-148. https://doi.org/10. 15255/CABEQ.2015.2231.

Vamvuka, D., Kakaras, E., 2011. Ash properties and environmental impact of various biomass and coal fuels and their blends. Fuel Process. Technol. 92, 570-581. https:// doi.org/10.1016/j.fuproc.2010.11.013.

Vamvuka, D., Zografos, D., Alevizos, G., 2008. Control methods for mitigating biomass ash-related problems in fluidized beds. Bioresour. Technol. 99, 3534-3544. https:// doi.org/10.1016/j.biortech.2007.07.049.

Vassilev, S.V., Baxter, D., Andersen, L.K., Vassileva, C.G., 2013a. An overview of the composition and application of biomass ash. Part 1. Phase - mineral and chemical composition and classification. Fuel 105, 40-76. https://doi.org/10.1016/j.fuel. 2012.09.041.

Vassilev, S.V., Baxter, D., Andersen, L.K., Vassileva, C.G., 2013b. An overview of the composition and application of biomass ash. Fuel 105, 19-39. https://doi.org/10. 1016/j.fuel.2012.10.001.

Vassilev, S.V., Baxter, D., Andersen, L.K., Vassileva, C.G., 2010. An overview of the chemical composition of biomass. Fuel 89, 913-933. https://doi.org/10.1016/j.fuel. 2009.10.022.

Vassilev, S.V., Baxter, D., Vassileva, C.G., 2014a. An overview of the behaviour of biomass during combustion: Part II. Ash fusion and ash formation mechanisms of biomass types. Fuel 117, 152-183. https://doi.org/10.1016/j.fuel.2013.09.024.

Vassilev, S.V., Vassileva, C.G., Baxter, D., 2014b. Trace element concentrations and associations in some biomass ashes. Fuel 129, 292-313. https://doi.org/10.1016/j.fuel. 2014.04.001.

Velay-Lizancos, M., Azenha, M., Martínez-Lage, I., Vázquez-Burgo, P., 2017. Addition of biomass ash in concrete: effects on E-Modulus, electrical conductivity at early ages and their correlation. Constr. Build. Mater. 157, 1126-1132. https://doi.org/10. 1016/j.conbuildmat.2017.09.179.

Wang, S., 2015. Cofired biomass fly ashes in mortar: reduction of Alkali Silica Reaction (ASR) expansion, pore solution chemistry and the effects on compressive strength. Constr. Build. Mater. 82, 123-132. https://doi.org/10.1016/j.conbuildmat.2015.02. 021.

Wang, S., Baxter, L., 2007. Comprehensive study of biomass fly ash in concrete: strength, microscopy, kinetics and durability. Fuel Process. Technol. 88, 1165-1170. https:// doi.org/10.1016/j.fuproc.2007.06.016 
Wang, S., Baxter, L., Fonseca, F., 2008a. Biomass fly ash in concrete: SEM, EDX and ESEM analysis. Fuel 87, 372-379. https://doi.org/10.1016/j.fuel.2007.05.024.

Wang, S., Llamazos, E., Baxter, L., Fonseca, F., 2008b. Durability of biomass fly ash concrete: freezing and thawing and rapid chloride permeability tests. Fuel 87 , 359-364. https://doi.org/10.1016/j.fuel.2007.05.027.

Wang, S., Miller, A., Llamazos, E., Fonseca, F., Baxter, L., 2008c. Biomass fly ash in concrete: mixture proportioning and mechanical properties. Fuel 87, 365-371. https://doi.org/10.1016/j.fuel.2007.05.026.

Wang, Y., Geng, S., Zhao, P., Du, H., He, Y., Crittenden, J., 2016. Cost - benefit analysis of GHG emission reduction in waste to energy projects of China under clean development mechanism. Resour. Conserv. Recycl. 109, 90-95. https://doi.org/10.1016/j. resconrec.2016.02.010.

WBCSD, I.E.A, 2009. Cement Technology Roadmap 2009: Carbon emissions reductions up to 205036 DOI: $978-3-940388-47-6$.

Wesche, K., 2004. Fly Ash in Concrete: Properties and performance. Rilem Report. Taylor
$\&$ Francis.

Xu, G., Shi, X., 2018. Characteristics and applications of fly ash as a sustainable construction material: a state-of-the-art review. Resour. Conserv. Recycl. 136, 95-109. https://doi.org/10.1016/j.resconrec.2018.04.010.

Yammine, J., Chaouche, M., Guerinet, M., Moranville, M., Roussel, N., 2008. From ordinary rhelogy concrete to self compacting concrete: a transition between frictional and hydrodynamic interactions. Cem. Concr. Res. 38, 890-896. https://doi.org/10. 1016/j.cemconres.2008.03.011.

Yang, D., Fan, L., Shi, F., Liu, Q., Wang, Y., 2017. Comparative study of cement manufacturing with different strength grades using the coupled LCA and partial LCC methods - a case study in China. Resour. Conserv. Recycl. 119, 60-68. https://doi. org/10.1016/j.resconrec.2016.06.017.

Yang, Z., Huddleston, J., Brown, H., 2016. Effects of Wood Ash on Properties of Concrete and Flowable Fill. pp. 101-114. 